\title{
Smallholder farms in eastern African tropical highlands have low soil greenhouse gas fluxes
}

\author{
David Pelster ${ }^{1}$, Mariana Rufino ${ }^{2,3}$, Todd Rosenstock ${ }^{4}$, Joash Mango ${ }^{4}$, Gustavo Saiz ${ }^{5, a}$, Eugenio Diaz-Pines ${ }^{5}$, \\ German Baldi $^{6}$, and Klaus Butterbach-Bahl ${ }^{1,5}$ \\ ${ }^{1}$ International Livestock Research Institute (ILRI), P.O. Box 30709, Nairobi, Kenya \\ ${ }^{2}$ Centre for International Forestry Research (CIFOR), P.O. Box 30677-00100, UN Avenue, Nairobi, Kenya \\ ${ }^{3}$ Lancaster Environment Centre, Lancaster University, Lancaster, LA1 4YQ, UK \\ ${ }^{4}$ World Agroforestry Centre (ICRAF), P.O. Box 30677-00100, UN Avenue, Nairobi, Kenya \\ ${ }^{5}$ Karlsruhe Institute of Technology - Institute of Meteorology and Climate Research, Institute of Atmospheric Environmental \\ Research (KIT/IMK-IFU), Kreuzeckbahnstr. 19, 82467 Garmisch-Partenkirchen, Germany \\ ${ }^{6}$ Grupo de Estudios Ambientales - IMASL, Universidad Nacional de San Luis and CONICET, Ejército de los Andes 950, \\ D5700HHW, San Luis, Argentina \\ a now at: Department of Life Sciences, Imperial College London, Silwood Park Campus, Buckhurst Road, \\ Ascot, Berkshire, SL5 7PY, UK
}

Correspondence to: David Pelster (d.pelster@cgiar.org)

Received: 31 July 2015 - Published in Biogeosciences Discuss.: 16 September 2015

Revised: 9 December 2016 - Accepted: 13 December 2016 - Published: 12 January 2017

\begin{abstract}
Few field studies examine greenhouse gas (GHG) emissions from African agricultural systems, resulting in high uncertainty for national inventories. This lack of data is particularly noticeable in smallholder farms in sub-Saharan Africa, where low inputs are often correlated with low yields, often resulting in food insecurity as well. We provide the most comprehensive study in Africa to date, examining annual soil $\mathrm{CO}_{2}, \mathrm{CH}_{4}$ and $\mathrm{N}_{2} \mathrm{O}$ emissions from 59 smallholder plots across different vegetation types, field types and land classes in western Kenya. The study area consists of a lowland area (approximately $1200 \mathrm{~m}$ a.s.1.) rising approximately $600 \mathrm{~m}$ to a highland plateau. Cumulative annual fluxes ranged from 2.8 to $15.0 \mathrm{MgCO}_{2}-\mathrm{Cha}^{-1}$, -6.0 to $2.4 \mathrm{~kg} \mathrm{CH}_{4}-\mathrm{Cha}^{-1}$ and -0.1 to $1.8 \mathrm{~kg} \mathrm{~N}_{2} \mathrm{O}-\mathrm{N} \mathrm{ha}^{-1}$. Management intensity of the plots did not result in differences in annual GHG fluxes measured $(P=0.46,0.14$ and 0.67 for $\mathrm{CO}_{2}, \mathrm{CH}_{4}$ and $\mathrm{N}_{2} \mathrm{O}$ respectively). The similar emissions were likely related to low fertilizer input rates $\left(\leq 20 \mathrm{~kg} \mathrm{Nha}^{-1}\right)$. Grazing plots had the highest $\mathrm{CO}_{2}$ fluxes $(P=0.005)$, treed plots (plantations) were a larger $\mathrm{CH}_{4}$ sink than grazing plots $(P=0.05)$, while soil $\mathrm{N}_{2} \mathrm{O}$ emissions were similar across vegetation types $(P=0.59)$. This study is likely representative for low fertilizer input, smallholder
\end{abstract}

systems across sub-Saharan Africa, providing critical data for estimating regional or continental GHG inventories. Low crop yields, likely due to low fertilization inputs, resulted in high (up to $67 \mathrm{~g} \mathrm{~N}_{2} \mathrm{O}-\mathrm{N} \mathrm{kg}^{-1}$ aboveground $\mathrm{N}$ uptake) yieldscaled emissions. Improvement of crop production through better water and nutrient management might therefore be an important tool in increasing food security in the region while reducing the climate footprint per unit of food produced.

\section{Introduction}

Increased atmospheric concentrations of greenhouse gases (GHGs: $\mathrm{CO}_{2}, \mathrm{~N}_{2} \mathrm{O}$ and $\mathrm{CH}_{4}$ ) over the last century have been correlated to increasing mean global temperature (IPCC, 2013); while $\mathrm{N}_{2} \mathrm{O}$ is also the primary ozone-depleting anthropogenically emitted gas (Ravishankara et al., 2009). Globally, agriculture is directly responsible for approximately $14 \%$ of anthropogenic GHG emissions while indirect emissions due to conversion of natural landscapes to agricultural systems may contribute an additional $17 \%$ (Vermeulen et al., 2012). In developing countries, however, agriculture can account for up to $66 \%$ of a country's total GHG emission 
(Tubiello et al., 2014), with African GHG emissions from agriculture and other land uses estimated to be $61 \%$ of total continental GHG emissions (Valentini et al., 2014).

In parts of the developing world, such as sub-Saharan Africa (SSA), smallholder farms (farm size $<10$ ha) comprise almost $80 \%$ of farmland and up to $90 \%$ of farms (Altieri and Koohafkan, 2008). Thus, it is likely that smallholder farms have a large effect on the GHG inventories of SSA. Unfortunately, there is a dearth of knowledge on agricultural soil GHG emissions from smallholder systems as only a handful of empirical studies (Table 1) have measured these (e.g., Baggs et al., 2006; Brümmer et al., 2008; Dick et al., 2006; Predotova et al., 2010). Previous studies in Africa were also limited in scope, measuring emissions from a low number of sites (generally less than 10) for a short time period (i.e., less than 1 year), often with low temporal resolution. This shortage of baseline data makes it impossible for many developing countries to accurately assess emissions from soils used for agriculture or to use Tier 2 methodology, which requires the development and documentation of country or regionally specific emission factors, to calculate GHG inventories (IPCC, 2006). Also, Tier 1 methodology assumes a linear response to fertilizer, which may not accurately reflect emissions in low input systems (Shcherbak et al., 2014). Finally, because most of the research behind the development of the Tier 1 methodology has been completed in temperate zones, the differences in climate, soils, farm management and nutrient balances (Vitousek et al., 2009) seem to result in consistent overestimates of GHG fluxes (Hickman et al., 2014b; Rosenstock et al., 2013b). This likely translates to inflated national agricultural GHG inventories in SSA that may result in incorrect targeting and inefficient mitigation measures.

Soil GHG emission rates have been related to soil properties such as pH, soil organic carbon (SOC) content or texture (Khan et al., 2011; Chantigny et al., 2010; Rochette et al., 2008; Stehfest and Bouwman, 2006) but also to vegetation (crop) type (Stehfest and Bouwman, 2006) and management operations, e.g., tillage, fertilizer type or crop rotation (Baggs et al., 2006; Drury et al., 2006; Grageda-Cabrera et al., 2004; Halvorson et al., 2008; Yamulki and Jarvis, 2002). In contrast to agricultural systems in most OECD (Organisation for Economic Co-operation and Development) states, smallholder farmers differentially allocate resources based on distance from homestead and perceived soil fertility, specifically manure and fertilizer applications, to their fields resulting in strong gradients in soil fertility (Tittonell et al., 2013). The differences in soil fertility can be predicted using remote sensing tools like the "normalized difference vegetation index" (NDVI) to determine the magnitude and temporal variability of primary productivity (Paruelo et al., 2001). Differences in fertility can also be predicted using farmer questionnaires to determine how farmers allocate resources to the fields and then using this typology of farming activities (hereafter "field typology") to estimate where soil GHG fluxes are more likely to be high. If strong correlations can be empiri- cally observed, such fertility gradients may then be upscaled based on either the NDVI or farmer interviews, further allowing for effective landscape-level predictions based on the field-scale GHG measurements.

The lack of good information on GHG fluxes related to agricultural activities in SSA and specifically on smallholder farming systems is a large data gap that needs to be addressed. The objectives of this study were to gather GHG flux data from smallholder farms of the western Kenyan Highlands that represent both the diversity in farming practices and the landscape heterogeneity typically found for many highland regions in eastern Africa. We hypothesized that (a) in view of low rates of fertilizer applications by smallholders, the GHG fluxes are generally at the low end of published fluxes from agricultural land, (b) the seasonality of rainfall is mirrored by fluxes and (c) differences in land productivity as reflected by NDVI and field typology as well as differences in vegetation can be used to explain spatial variability in field-scale soil GHG fluxes.

\section{Materials and methods}

The study site was a $10 \mathrm{~km} \times 10 \mathrm{~km}$ area in Kisumu County, western Kenya (centered at $35.023^{\circ} \mathrm{E}, 0.315^{\circ} \mathrm{S}$ ), north of the town of Sondu (Fig. 1) and ranged from a lowland area at approximately $1200 \mathrm{~m}$ a.s.l. to a highland plateau at approximately $1800 \mathrm{~m}$ a.s.l. The site is one of the sentinel sites for the CGIAR Research Program on Climate Change, Agriculture and Food Security (CCAFS) and is described in detail in Sijmons et al. (2013). This site was selected as it was found to be broadly similar in terms of demographics (e.g., population density, income) and agro-ecological characteristics (e.g., elevation, temperature, precipitation) of other eastern African tropical highlands (Braun et al., 1997), allowing us to scale up the results to other countries in the region (Sijmons et al., 2013). Mean annual temperature is approximately $23^{\circ} \mathrm{C}$ and the average annual rainfall is $1150 \mathrm{~mm}$ (Köppen classification of a tropical savanna climate). Temperatures tend to be slightly cooler and precipitation slightly higher in the highlands compared to the lower regions of the study site. Precipitation patterns are bimodal with the "long rains" occurring from April to June ( $42 \%$ of annual precipitation) and the "short rains" occurring from October through December ( $26 \%$ of annual precipitation). The site is primarily composed of smallholder rain-fed farms typically growing maize (Zea mays) and sorghum (Sorghum bicolor) during the long rains and beans during the short rains. Based on farmer interviews, approximately $27 \%$ of them applied fertilizers (i.e., manure or synthetic fertilizers) to their plots, with application rates being very low. For manure, application rates were approximately $200 \mathrm{~kg}$ manure ha ${ }^{-1}$, which corresponds to approximately $95 \mathrm{~kg}$ of $\mathrm{C}$ and $5 \mathrm{~kg}$ of $\mathrm{N}$ given typical $\mathrm{N}$ contents for cattle in this region (Pelster et al., 2016). While application rates for synthetic fertilizer (two farmers applied diammonium phosphate and one applied urea) were 
Table 1. List of in situ empirical studies of greenhouse gas fluxes from agricultural systems in sub-Saharan Africa.

\begin{tabular}{|c|c|c|c|c|c|}
\hline Reference & $\begin{array}{l}\text { Location (and crop } \\
\text { type/treatment) }\end{array}$ & Sites & Time of measurement & $\begin{array}{l}\text { Sampling } \\
\text { frequency }\end{array}$ & Flux rates $^{\mathrm{d}}$ \\
\hline \multicolumn{6}{|l|}{ Annual flux estimates } \\
\hline $\begin{array}{l}\text { Brümmer et al. (2008, } \\
\text { 2009) }\end{array}$ & $\begin{array}{l}\text { Burkina Faso } \\
\text { (sorghum, cotton } \\
\text { or peanut) }\end{array}$ & 4 & $\begin{array}{l}\text { Jun-Sep } 2005 \\
\text { Apr-Sep } 2006\end{array}$ & 1-3 times per week & $\begin{array}{l}\mathrm{N}_{2} \mathrm{O}: 0.19-0.67 \mathrm{~kg} \mathrm{ha}^{-1} \mathrm{yr}^{-1} \\
\mathrm{CO}_{2}: 2.5-4.1 \mathrm{Mg} \mathrm{ha}^{-1} \mathrm{yr}^{-1} \\
\mathrm{CH}_{4}:-0.67 \text { to }-0.7 \mathrm{~kg} \mathrm{ha}^{-1} \mathrm{yr}^{-1}\end{array}$ \\
\hline Dick et al. $(2008)^{\mathrm{a}}$ & $\begin{array}{l}\text { Mali (pearl millet } \\
\text { with/without legume } \\
\text { intercropping) }\end{array}$ & 3 & Jan 2004-Feb 2005 & Monthly & $\mathrm{N}_{2} \mathrm{O}: 0.9-1.5 \mathrm{~kg} \mathrm{ha}^{-1} \mathrm{yr}^{-1}$ \\
\hline Hickman et al. (2015) & Kenya (maize) & 1 & $\begin{array}{l}\text { Mar 2011-Jul } 2011 \\
\text { Apr 2012-Jan } 2013\end{array}$ & Daily to weekly & $\mathrm{N}_{2} \mathrm{O}: 0.1-0.3 \mathrm{~kg} \mathrm{ha}^{-1} \mathrm{yr}^{-1}$ \\
\hline Koerber et al. $(2009)^{b}$ & Uganda (vegetables) & 24 & Jul 2005-Sep 2006 & Monthly & $\mathrm{CO}_{2}: 30.3-38.5 \mathrm{Mg} \mathrm{ha}^{-1} \mathrm{yr}^{-1}$ \\
\hline Lompo et al. $(2012)^{c}$ & $\begin{array}{l}\text { Burkina Faso } \\
\text { (urban gardens) }\end{array}$ & 2 & Mar 2008-Mar 2009 & $\begin{array}{l}\text { Twice a day (“sev- } \\
\text { eral" times per } \\
\text { cropping period) }\end{array}$ & $\begin{array}{l}\mathrm{N}_{2} \mathrm{O}: 80.5-113.4 \mathrm{~kg} \mathrm{ha}^{-1} \mathrm{yr}^{-1} \\
\mathrm{CO}_{2}: 22-36 \mathrm{Mg} \mathrm{ha}^{-1} \mathrm{yr}^{-1}\end{array}$ \\
\hline Makumba et al. (2007) & $\begin{array}{l}\text { Malawi (maize with } \\
\text { agroforestry) }\end{array}$ & 1 & Oct 2001-Apr 2002 & Weekly & $\mathrm{CO}_{2}: 2.6-7.8 \mathrm{Mg} \mathrm{ha}^{-1} \mathrm{yr}^{-1}$ \\
\hline Predotova et al. $(2010)^{\mathrm{c}}$ & $\begin{array}{l}\text { Niger (urban and peri- } \\
\text { urban gardens) }\end{array}$ & 3 & Apr 2006-Feb 2007 & $\begin{array}{l}\text { Twice a day for } 6 \\
\text { days (repeated } \\
8-9 \text { times per year) }\end{array}$ & $\begin{array}{l}\mathrm{N}_{2} \mathrm{O}: 48-92 \mathrm{~kg} \mathrm{ha}^{-1} \mathrm{yr}^{-1} \\
\mathrm{CO}_{2}: 20-30 \mathrm{Mg} \mathrm{ha}^{-1} \mathrm{yr}^{-1}\end{array}$ \\
\hline Sugihara et al. $(2012)^{\mathrm{b}}$ & $\begin{array}{l}\text { Tanzania (maize, } \\
\text { with/without residue) }\end{array}$ & 2 & Mar 2007-June 2010 & $\begin{array}{l}1-2 \text { times per } \\
\text { month }\end{array}$ & $\mathrm{CO}_{2}: 0.9-4.0 \mathrm{Mg} \mathrm{ha}^{-1} \mathrm{yr}^{-1}$ \\
\hline This study & $\begin{array}{l}\text { Kenya (annual crops, } \\
\text { grazing land, woodlots, } \\
\text { fodder grasses) }\end{array}$ & 59 & Aug 2013-Aug 2014 & Weekly & $\begin{array}{l}\mathrm{N}_{2} \mathrm{O}:-0.13-1.83 \mathrm{~kg} \mathrm{ha}^{-1} \mathrm{yr}^{-1} \\
\mathrm{CO}_{2}: 2.8-15.0 \mathrm{Mg} \mathrm{ha}^{-1} \mathrm{yr}^{-1} \\
\mathrm{CH}_{4}:-5.99-2.44 \mathrm{~kg} \mathrm{ha}^{-1} \mathrm{yr}^{-1}\end{array}$ \\
\hline \multicolumn{6}{|l|}{ Seasonal flux estimates } \\
\hline Baggs et al. (2006) & $\begin{array}{l}\text { Kenya (maize with } \\
\text { agroforestry, till/no till) }\end{array}$ & 1 & $\begin{array}{l}\text { Feb-June } 2002 \\
\text { (rainy season) }\end{array}$ & Weekly & $\begin{array}{l}\mathrm{N}_{2} \mathrm{O}: 0.2-0.6 \mathrm{~kg} \mathrm{ha}^{-1} \\
\mathrm{CO}_{2}: 1.8-2.3 \mathrm{Mg} \mathrm{ha}^{-1} \\
\mathrm{CH}_{4}: 0.1-0.3 \mathrm{~kg} \mathrm{ha}^{-1}\end{array}$ \\
\hline $\begin{array}{l}\text { Chapuis-Lardy et } \\
\text { al. (2009) }\end{array}$ & $\begin{array}{l}\text { Madagascar (maize } \\
\text { with soybean) }\end{array}$ & 1 & $\begin{array}{l}\text { Nov 2006-Apr } 2007 \\
\text { (rainy season) }\end{array}$ & Weekly & $\mathrm{N}_{2} \mathrm{O}: 0.3 \mathrm{~kg} \mathrm{ha}^{-1}$ \\
\hline Chikowo et al. (2004) & $\begin{array}{l}\text { Zimbabwe } \\
\text { (maize/improved } \\
\text { fallow) }\end{array}$ & 1 & $\begin{array}{l}\text { Dec 2000-Feb } 2001 \\
\text { (rainy season) }\end{array}$ & Weekly & $\mathrm{N}_{2} \mathrm{O}: 0.1-0.3 \mathrm{~kg} \mathrm{ha}^{-1}$ \\
\hline $\begin{array}{l}\text { Hickmann et al. } \\
\text { (2014a) }\end{array}$ & $\begin{array}{l}\text { Kenya (maize with dif- } \\
\text { ferent fertilizer rates) }\end{array}$ & 1 & Mar-Jul 2010 & Daily to weekly & $\mathrm{N}_{2} \mathrm{O}: 0.62-0.81 \mathrm{~kg} \mathrm{ha}^{-1} \mathrm{yr}^{-1}$ \\
\hline Mapanda et al. (2011) ${ }^{\mathrm{b}}$ & $\begin{array}{l}\text { Zimbabwe (maize with } \\
\text { different fertilizer rates } \\
\text { and types) }\end{array}$ & 2 & $\begin{array}{l}\text { Nov 2006-Jan } 2007 \\
\text { Nov 2007-Apr } 2008 \\
\text { Nov 2008-Apr } 2009 \\
\text { (rainy season) }\end{array}$ & $\begin{array}{l}\text { Once every } 2 \\
\text { months }\end{array}$ & $\begin{array}{l}\mathrm{N}_{2} \mathrm{O}: 0.1-0.5 \mathrm{~kg} \mathrm{ha}^{-1} \\
\mathrm{CO}_{2}: 0.7-1.6 \mathrm{Mg} \mathrm{ha}^{-1} \\
\mathrm{CH}_{4}:-2.6 \text { to }+5.8 \mathrm{~kg} \mathrm{ha}^{-1}\end{array}$ \\
\hline Millar et al. (2004) & $\begin{array}{l}\text { Kenya (maize with } \\
\text { regular and improved } \\
\text { fallow) }\end{array}$ & & $\begin{array}{l}\text { Sep-Dec } 1999 \\
\text { Mar- Jun } 2000 \\
\text { (rainy season) }\end{array}$ & 1-2 times per week & $\begin{array}{l}\mathrm{N}_{2} \mathrm{O}: 0.1-4.1 \mathrm{~kg} \mathrm{ha}^{-1} \\
\mathrm{CO}_{2}: 0.7-1.7 \mathrm{Mg} \mathrm{ha}^{-1}\end{array}$ \\
\hline \multicolumn{6}{|c|}{ Mean flux rates from short duration studies } \\
\hline Kimetu et al. (2007) & Kenya (maize) & 1 & $\begin{array}{l}\text { Mar-Jun } 2000 \\
\text { (rainy season) }\end{array}$ & 3 times per month & $\mathrm{N}_{2} \mathrm{O}: 1.3-12.3 \mu \mathrm{g} \mathrm{m}^{-2} \mathrm{~h}^{-1}$ \\
\hline Mapanda et al. $(2010)^{\mathrm{b}}$ & $\begin{array}{l}\text { Zimbabwe (grassland/ } \\
\text { grazing, tree } \\
\text { plantations and maize) }\end{array}$ & 12 & $\begin{array}{l}\text { Nov 2006-Mar } 2007 \\
\text { (rainy season) }\end{array}$ & $\begin{array}{l}\text { Twice a month } \\
\text { to once every } 2 \\
\text { months }\end{array}$ & $\begin{array}{l}\mathrm{N}_{2} \mathrm{O}: 1.0-4.7 \mu \mathrm{g} \mathrm{m}^{-2} \mathrm{~h}^{-1} \\
\mathrm{CO}_{2}: 22.5-46.8 \mathrm{mg} \mathrm{m}^{-2} \mathrm{~h}^{-1} \\
\mathrm{CH}_{4}:-9.4 \text { to }+6.9 \mu \mathrm{g} \mathrm{m}^{-2} \mathrm{~h}^{-1}\end{array}$ \\
\hline Thomas (2012) & Botswana (grazing) & 2 & $\begin{array}{l}\text { Feb, Apr, Jul, Nov } 2010 \\
\text { (both rainy and dry } \\
\text { season) }\end{array}$ & $\begin{array}{l}7 \text { times per day, } 12 \\
\text { separate days only }\end{array}$ & $\mathrm{CO}_{2}: 1.1-42.1 \mathrm{mg} \mathrm{m}^{-2} \mathrm{~h}^{-1}$ \\
\hline
\end{tabular}

a Study includes fertilization up to $200 \mathrm{~kg} \mathrm{~N} \mathrm{ha}^{-1}$.

b Sampling is too infrequent for accurate estimates of cumulative fluxes (Barton et al., 2015).

${ }^{c}$ Uses photoacoustic spectroscopy, which has recently had questions raised about its accuracy (Rosenstock et al., 2013a); also, these studies used exceptionally high $\mathrm{N}$ application rates from 473 to approximately $4000 \mathrm{~kg} \mathrm{Nha}^{-1} \mathrm{yr}^{-1}$.

${ }^{\mathrm{d}}$ Note: flux rates are given as the range of values from the various replicates used in the studies, i.e., the spatial variability and, where available (Mapanda et al. 2011 and Thomas 2012), the temporal variability, are reported as $\mathrm{N}-\mathrm{N}_{2} \mathrm{O}, \mathrm{C}-\mathrm{CO}_{2}$ and $\mathrm{C}_{-} \mathrm{CH}_{4}$. Please also note units: where possible, annual cumulative fluxes are presented, however, in cases with insufficient data to

estimate cumulative annual fluxes, we present either mean flux rates or the cumulative for the given period. 

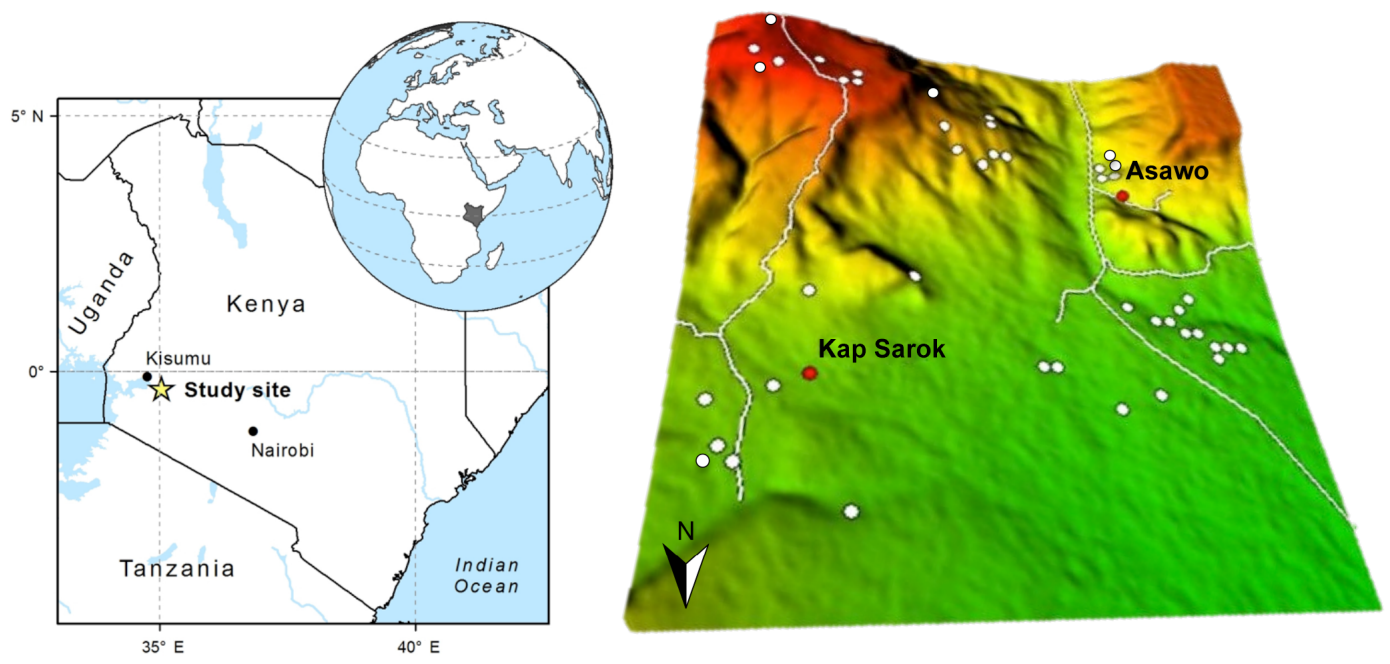

Figure 1. Map of study area showing the sampling location by the different vegetation cover types.

Table 2. Soil properties ( \pm 1 SEM (standard error of the mean)) for 0 to $20 \mathrm{~cm}$ depth, sampled immediately before initiation of gas sampling for the different land classes.

\begin{tabular}{lccccc}
\hline Land class & $\mathrm{C} \mathrm{content}^{\mathrm{b}}(\%)$ & $\mathrm{N}$ content $(\%)$ & $\mathrm{C} / \mathrm{N}$ ratio & $\mathrm{pH}$ & $\mathrm{Bulk} \mathrm{density}\left(\mathrm{g} \mathrm{cm}^{-3}\right)$ \\
\hline $\begin{array}{l}\text { (1) Lowland small }(<2 \text { ha) mixed farms } \\
\text { with degradation signs }^{\mathrm{a}}(n=7)\end{array}$ & $1.38 \pm 0.13$ & $0.10 \pm 0.01$ & $13.18 \pm 0.51$ & $6.61 \pm 0.09$ & $0.86 \pm 0.03$ \\
\hline $\begin{array}{l}\text { (2) Lower slopes }{ }^{\mathrm{c}} \text {, moderate-sized } \\
(2-5 \text { ha) mixed farms with degradation }\end{array}$ & $1.18 \pm 0.14$ & $0.10 \pm 0.01$ & $11.60 \pm 0.58$ & $6.58 \pm 0.16$ & $1.14 \pm 0.08$ \\
signs $(n=8)$ & & & & \\
\hline $\begin{array}{l}\text { (3) Mid-slopes, moderate-sized grazing } \\
\text { land }(n=10)\end{array}$ & $2.27 \pm 0.37$ & $0.18 \pm 0.03$ & $12.16 \pm 0.42$ & $6.02 \pm 0.21$ & $0.98 \pm 0.07$ \\
\hline $\begin{array}{l}\text { (4) Upper slopes/highland plateau, } \\
\text { mixed farms }(n=22)\end{array}$ & $2.67 \pm 0.17$ & $0.21 \pm 0.02$ & $12.69 \pm 0.52$ & $5.46 \pm 0.24$ & $0.80 \pm 0.06$ \\
\hline $\begin{array}{l}\text { (5) Mid-slopes, isolated moderate-sized } \\
\text { farms }(n=12)\end{array}$ & $2.83 \pm 0.36$ & $0.24 \pm 0.02$ & $13.02 \pm 0.81$ & $5.84 \pm 0.20$ \\
\hline
\end{tabular}

\footnotetext{
${ }^{a}$ Degradation signs were bare soil and evidence of erosion visible on MODIS images.

${ }^{b}$ Due to lack of carbonates, total $\mathrm{C}$ equals organic $\mathrm{C}$.

${ }^{\mathrm{c}}$ Sloped areas went from the lowlands (approx. $1200 \mathrm{~m}$ a.s.1.) up to the highlands (approx. $1800 \mathrm{~m}$ a.s.l.) ranging from 10 to $30 \%$.
}

$<50 \mathrm{~kg}$ fertilizer ha ${ }^{-1}\left(<25 \mathrm{~kg} \mathrm{~N} \mathrm{ha}^{-1}\right)$. These fertilizer rates are much lower than rates typical for industrial production where application rates often exceed $150 \mathrm{~kg} \mathrm{~N} \mathrm{ha}^{-1}$ for maize production.

Soil types in the study area are highly heterogeneous, ranging from well-drained, acidic Nitisols in the upper part of the landscape, to eutric and dystric Cambisols in mid-altitude areas and poorly drained Planosols in the lower parts (IUSS Working Group WRB, 2015). Selected topsoil characteristics for the different land classes identified in the study region are provided in Table 2.

\subsection{Landscape stratification}

Differences in management intensity and vegetation were expected to affect GHG fluxes, and so the landscape was stratified to account for the expected variability. The stratification was based on a mixed method land use classification combining remote sensing and household surveys.

For the land classification we followed an approach based on vegetation functioning in terms of the magnitude and the temporal variability of primary productivity (Paruelo et al., 2001), assessed through the proxy variable NDVI, which allows approximate but widespread characterizations of productivity across space and time and across different ecosystems (Lloyd, 1990; Xiao et al., 2004). We acquired 20012012 NDVI data from MODIS (Moderate Resolution Imag- 
ing Spectroradiometer). We selected only those NDVI values indicating good to excellent quality conditions (i.e., pixels not covered by clouds and with a low to intermediate aerosol contamination). Then, we used the program TIMESAT version 3.1 to reconstruct temporal series (Jönsson and Eklundh, 2002).

From the reconstructed temporal series we assessed six functional metrics depicting the magnitude, seasonality and interannual variability of productivity. The metrics used were as follows: (1) the mean annual NDVI, (2) the minimum NDVI, (3) the browning rate (rate of NDVI decrease), (4) the peak of the NDVI, (5) the intra-annual coefficient of variation (CV) of the NDVI and (6) the interannual CV of the NDVI. These metrics allow us to differentiate between land cover types (e.g., cultivated vs. uncultivated) and between different cultivation management approaches (e.g., commercial intensive vs. subsistence) (Baldi et al., 2015). The different elevation bands and soil types resulted in different magnitudes, seasonality and interannual variability of productivity with the highlands generally having higher productivity due to the higher rainfall and more fertile soils. We then ran an ISODATA unsupervised classification algorithm (Jensen, 1996), and the resulting spectral classes were aggregated to create patches. After combining minor or sparsely distributed patches, we ended up with five classes characterized by the following features: (1) lowland subsistence farms with degradation signs $(n=7),(2)$ lower slopes, moderate-sized mixed farms $(n=8)$, (3) mid-slopes, moderate-sized, primarily grazing/shrubland $(n=10)$, (4) upper slopes/highland plateau, mixed farms $(n=22)$ and (5) mid-slopes, moderatesized mixed farms $(n=12)$.

We also stratified the plots by field typology using the following variables to define a field type score as follows. (1) Crop: this score is the sum of the crop types each household is cultivating in one plot. (2) Fertilizer use: this score distinguishes organic and inorganic fertilizers. (3) Number of subplots: allowing us to capture the spatial and temporal allocation of land to crops, crop mixtures, and combination of annual and perennial crops in intercropping, permanent and seasonal grazing land. (4) Location of field: the assumption being that fields close to the homestead receive preferential land management (fertilization, addition of organic amendments, weeding etc.) when compared to fields that are far away (Tittonell et al., 2013). (5) Signs of erosion: fields obtained a different score depending on the severity of the visible signs of erosion. Plots were scored based on the preceding information and those with a higher score were considered field type $1(n=17)$, those with a low score were considered field type $3(n=19)$ and those plots with intermediate scores were assigned a field type $2(n=23)$. It was assumed that field type 1 was the most intensively managed (i.e., more fertilizer/manure additions) and field type 3 the least managed (i.e., none to very low fertilizer additions, degraded, low soil C). For a more detailed description of the stratification process; see Rufino et al. (2016).
Finally, the plots were stratified by vegetation (cover) type: treed/bush (generally plantations of either Grevillea spp. or Eucalyptus spp.) $(n=7)$, perennial grasses/grazing $(n=15)$ and annual cropping $(n=37)$. Initially, the total number of sample plots was 60 , with the number per category based partly on the area covered by each specific land classification/field type/vegetation type combination and partly on logistical constraints (i.e., access). One plot however, was converted into a construction site in late 2013, resulting in only 59 plots being measured for the full year.

\subsection{Field soil GHG flux survey}

At the 59 field sites (see above and Fig. 1) soil $\mathrm{CO}_{2}, \mathrm{~N}_{2} \mathrm{O}$ and $\mathrm{CH}_{4}$ fluxes were measured weekly, starting at the week of 12 August 2013 through to 12 August 2014 (one full year including two growing seasons) using non-flow-through non-steady-state chambers (Rochette, 2011; Sapkota et al., 2014). Given the large number of sites and the difficult access, this required four 2-person crews sampling 4 days per week. Briefly, four rectangular $(0.35 \mathrm{~m} \times 0.25 \mathrm{~m})$ hard plastic frames per site were inserted $0.10 \mathrm{~m}$ into the ground. Fields planted with annual crops were ploughed, either using an ox-pulled plough or by hand, twice during this period, which meant that the frames needed to be removed and then reinstalled; however, where possible, the chamber frames were left undisturbed for the entire period. For fields planted with annual crops, the frames were installed between the rows and were weeded the same week the farmers weeded the rest of the field. The chambers in the grazing and treed plots would have included some vegetation (primarily grasses), but these were kept short $(<5 \mathrm{~cm}$ long) by the continual grazing. On each sampling date, an opaque, vented and insulated lid $(0.125 \mathrm{~m}$ height $)$ covered with reflective tape was tightly fitted to the base (Rochette, 2011). The lid was also fitted with a small fan to ensure proper mixing of the headspace and air samples $(15 \mathrm{~L})$ were collected from the headspace at $0,15,30$ and $45 \mathrm{~min}$ after deployment using a syringe through a rubber septum. Even with the insulation and reflective tape on the chambers, the air temperature inside the chambers still increased during deployment (approximately $10^{\circ} \mathrm{C}$ on average), which may slightly affect microbial and root activity in the soil underneath the chamber. The increase in temperature inside the chamber headspace would also cause some bias in the calculation of mixing ratios, which was estimated to be about $3 \%$.

To increase the number of sites measured while still accounting for the representativeness of flux measurements in view of expected high spatial variability of fluxes at fieldscale samples were pooled from the four replicate chambers at each plot (Arias-Navarro et al., 2013) to form a composite air sample of $60 \mathrm{~mL}$. This method has been found to provide flux estimates within 8 and $4 \%$ (for $\mathrm{CO}_{2}$ and $\mathrm{N}_{2} \mathrm{O}$ respectively) of the estimates calculated by separate sampling, although it is unclear which is the more accurate depiction of 
the true mean. Also, as noted by Arias-Navarro et al. (2013), this precludes the ability to examine within-site variability. However, we believed that the trade-off between on-site variability and sampling a broader range of sites was worthwhile given our aims of characterizing emissions in a way that captured both the diversity in farming practices and landscape heterogeneity typically found for many highland regions in eastern Africa. The first $40 \mathrm{~mL}$ of the sample was used to flush a $10 \mathrm{~mL}$ sealed glass vial through a rubber septum, while the final $20 \mathrm{~mL}$ was transferred into the vial to achieve an overpressure to minimize the risk of contamination by ambient air. The gas samples were analyzed within 10 days of sample collection for $\mathrm{CO}_{2}, \mathrm{CH}_{4}$ and $\mathrm{N}_{2} \mathrm{O}$ in an SRI 8610C gas chromatograph (2.74 m Hayesep-D column) fitted with a ${ }^{63} \mathrm{Ni}$-electron capture detector for $\mathrm{N}_{2} \mathrm{O}$ and a flame ionization detector for $\mathrm{CH}_{4}$ and $\mathrm{CO}_{2}$ (after passing the $\mathrm{CO}_{2}$ through a methanizer). The flow rate for the carrier gas $\left(\mathrm{N}_{2}\right)$ was $20 \mathrm{~mL} \mathrm{~min}^{-1}$. Every fifth sample analyzed on the gas chromatograph was a calibration gas (gases with known $\mathrm{CO}_{2}, \mathrm{CH}_{4}$ and $\mathrm{N}_{2} \mathrm{O}$ concentrations in synthetic air) and the relation between the peak area from the calibration gas and its concentration was used to determine the $\mathrm{CO}_{2}, \mathrm{CH}_{4}$ and $\mathrm{N}_{2} \mathrm{O}$ concentrations of the headspace samples.

\subsection{Calculation of soil GHG fluxes}

Soil GHG fluxes were calculated by the rate of change in concentration over time in the chamber headspace (corrected for mean chamber temperature and air pressure) after chamber deployment, as shown in Eq. (1).

$F_{\mathrm{GHG}}=(\partial c / \partial t) *\left(M / V_{\mathrm{m}}\right) *(V / A)$,

where $F_{\mathrm{GHG}}$ is the flux of the GHG in question, $\partial c / \partial t$ is the change in concentration over time, $M$ is the molar mass of the element in question ( $\mathrm{N}$ for $\mathrm{N}_{2} \mathrm{O}$ and $\mathrm{C}$ for $\mathrm{CO}_{2}$ and $\mathrm{CH}_{4}$ ), $V_{\mathrm{m}}$ is the molar volume of gas at the sampling temperature and atmospheric pressure, $V$ is the volume of the chamber headspace and $A$ is the area covered by the chamber.

For calculating the change in the GHG concentration over time, nonlinear models are generally less biased than linear models; however, they also tend to be very sensitive to outliers (Rochette, 2011). Therefore, when there was a strong correlation for the nonlinear model $\left(R^{2}>0.95\right)$ we used a second-order polynomial; otherwise, we used a linear model. See Rochette and Bertrand (2008) for details on these models. If however the $R^{2}<0.95$ for the nonlinear model and $<0.64$ for the linear model, we assumed there was no valid flux measurement and the data point was thrown out. We validated the data for each chamber measurement by examining the dynamics of the $\mathrm{CO}_{2}$ concentrations over the $45 \mathrm{~min}$ deployment period. Chambers that experienced a decrease in $\mathrm{CO}_{2}$ greater than $10 \%$ between any of the measurement times were assumed to have a leak and all GHG fluxes were discarded unless the decrease occurred in the last measurement; in this latter case, the flux rate was calculated with the first three measurement points. In cases where the change in concentration was lower than the precision of the instrument, we assumed zero flux. The minimum flux detection limits (Parkin et al., 2012) were 3.61 and $12.46 \mu \mathrm{g} \mathrm{N}_{2} \mathrm{O}-\mathrm{N} \mathrm{m}^{-2} \mathrm{~h}^{-1}$, and 0.015 and $0.051 \mathrm{mg} \mathrm{CH}_{4}-\mathrm{C} \mathrm{m}^{-2} \mathrm{~h}^{-1}$ for the linear and nonlinear models respectively. Also, negative fluxes for $\mathrm{CO}_{2}$ were deleted while negative $\mathrm{CH}_{4}$ and $\mathrm{N}_{2} \mathrm{O}$ fluxes were accepted as uptake of either in upland soils is feasible. To minimize measurement error and uncertainty, we used methods that were ranked as either "good" or "very good" for 15 of the 16 criteria selected by Rochette and Eriksen-Hamel (2008), with only the deployment time exceeding the recommended time by about $10 \%$. Cumulative annual fluxes were estimated for each plot using trapezoidal integration between sampling dates.

\subsection{Soil analysis}

At the beginning of the experiment and for each sampled site, five replicate soil samples were taken both at $0-5$ and $5-20 \mathrm{~cm}$ depths with a stainless steel corer $(40 \mathrm{~mm}$ inner diameter). Samples were individually placed in labeled ziplock bags. All soil material was oven-dried at $40^{\circ} \mathrm{C}$ for a week with large clumps being progressively broken by hand. Carbon and $\mathrm{N}$ concentrations were determined on powdered samples using an elemental combustion system (Costech International S.p.A., Milan, Italy) fitted with a zero-blank autosampler. Soil $\mathrm{pH}$ was measured in a $2: 1$ water : soil solution. Soil texture was determined gravimetrically as described by van Reeuwijk (2002).

In addition, soil samples were collected periodically (every 2 months) for determination of inorganic $\mathrm{N}$ concentrations. Briefly, the topsoil $(0-10 \mathrm{~cm}$ depth) was collected using a soil auger. Three samples from each plot were collected and pooled to form one composite sample. These were taken back to the lab and stored $\left(4^{\circ} \mathrm{C}\right)$ for less than 1 week before extraction $(1: 5$ soil : solution $w: v$ ratio) with $2 M \mathrm{KCl}$. Extracts were kept frozen until analyzed. Analysis for $\mathrm{NO}_{3}-\mathrm{N}$ was done via reduction with vanadium, with development of color $(540 \mathrm{~nm})$ using sulfanilic acid and naphthyl ethylenediamine and measurement of light absorbance on an Epoch microplate spectrophotometer (BioTek, Winooski, Vermont, USA). The $\mathrm{NH}_{4}-\mathrm{N}$ concentrations were measured using the green indophenol method $(660 \mathrm{~nm})$ using the same spectrophotometer (Bolleter et al., 1961).

\subsection{Environmental data}

Environmental data were collected at two sites, one in the uplands $\left(35.056^{\circ} \mathrm{E}, 0.351^{\circ} \mathrm{S}, 1676 \mathrm{~m}\right.$ a.s.l. $)$ and the other in the lowlands $\left(34.988^{\circ} \mathrm{E}, 0.308^{\circ} \mathrm{S}, 1226 \mathrm{~m}\right.$ a.s.l.). Each of the two weather stations was installed at a farm where we also measured GHG emissions. Air temperature was measured using a Decagon ECT (Decagon Devices, Pullman, Washington, USA) air temperature sensor (measurement ev- 
ery $5 \mathrm{~min}$ ), while precipitation data were collected with a Decagon ECRN-100 high-resolution, double-spoon tipping bucket rain gauge. Soil moisture and temperature were measured using a Decagon MPS-2 water potential and temperature sensor. Data were logged on a Decagon Em50 data collection system and downloaded periodically (typically monthly).

Air temperature, soil temperature and soil moisture $(5 \mathrm{~cm}$ depth) were also measured at each site at the time of gas sampling using a ProCheck handheld datalogger outfitted with a GS3 sensor (Decagon Devices).

\subsection{Plant production}

To estimate crop yields and crop $\mathrm{N}$ content of annual crops in the study area, we randomly selected nine of the study plots including annual crops. There were four plots with maize, four with sorghum and one with green grams (Vigna radiata (L.) R. Wilczek). In June 2013, all the plants within a $2.5 \mathrm{~m} \times 2.5 \mathrm{~m}$ square near the center of the field (i.e., to avoid edge effects) were harvested and the grains were removed from the plant. Both the stover and grains were dried for $48 \mathrm{~h}$ at $60^{\circ} \mathrm{C}$ and then weighed. A subsample of the grains was then ground and analyzed for $\mathrm{C}$ and $\mathrm{N}$ content on the same elemental combustion system described above for soil analysis. Yield-scaled $\mathrm{N}_{2} \mathrm{O}$ emissions $\left(\mathrm{g} \mathrm{N}_{2} \mathrm{O}-\mathrm{N} \mathrm{kg}^{-1}\right.$ aboveground $\mathrm{N}$ uptake) were calculated for each site by dividing the cumulative emissions of the growing season by the grain yields. The growing season lasted from mid-March to $\mathrm{Au}$ gust, which corresponds to the period between preparation of fields for the long rains through harvest and up to the preparation of the fields for the following growing season. No estimate of crop yields (or yield-scaled emissions) was done for the second growing season.

\subsection{Statistical analysis}

Correlations between GHG fluxes and soil properties were tested using Pearson's correlation. The cumulative field fluxes for a 4-week period during the dry season were compared to cumulative fluxes for a 4-week period during the rainy season using ANOVA (AOV in RStudio version 0.98.953) with the season and management practices (ploughed versus not ploughed for $\mathrm{CO}_{2}$ and fertilized versus not fertilized for $\mathrm{N}_{2} \mathrm{O}$ ) as fixed factors along with the twoway interaction terms. Cumulative field annual GHG fluxes were compared with ANOVA using an unbalanced design and cover type, land class and field type as fixed factors. In all cases, the distributions of flux measurements were tested for normality using the Shapiro-Wilk test. Cumulative soil $\mathrm{N}_{2} \mathrm{O}$ fluxes were not normally distributed and were transformed using the natural $\log$.

\section{Results}

\subsection{Field meteorological and site observations}

The soils were slightly acidic to neutral, ranging in $\mathrm{pH}$ from 4.4 to 7.5 (mean $=6.0)$. Carbon and $\mathrm{N}$ contents ranged from 0.7 to $4.0 \%($ mean $=2.2)$ and 0.07 to $0.33 \%($ mean $=0.17)$ respectively (Table 2 ). The $\mathrm{C} / \mathrm{N}$ ratio ranged from 7.7 to 18.1 (mean $=12.6$ ) and the $\mathrm{C}$ and $\mathrm{N}$ contents in the top $20 \mathrm{~cm}$ of the soil were highly correlated with each other $(R=0.976$; $P<0.0001)$.

Annual precipitation (15 August 2013 through 14 August 2014) in the lowlands was $1127 \mathrm{~mm}$ while there was $1417 \mathrm{~mm}$ precipitation in the highlands, a $25 \%$ increase with the $450 \mathrm{~m}$ elevation difference between the two stations. The average minimum and maximum daily temperatures in the lowlands were 15.6 and $30.5^{\circ} \mathrm{C}$ respectively, while temperatures were slightly cooler in the highlands, with an average minimum of 12.6 and an average maximum of $26.9^{\circ} \mathrm{C}$. Comparing the precipitation at the sites to a longterm 40-year (1960 to 2000) precipitation data set for the two nearby towns of Kisumu and Kericho (data available at http://africaopendata.org), we see that annual precipitation was within $10 \%$ of the long-term average. The monthly rainfalls were generally similar to long-term trends, with the exception of the rainfall in December, which was $26 \%$ of the long-term average, and the rainfall in March, which was 2fold higher than the long-term mean.

\subsection{Field-scale soil GHG fluxes and ancillary information}

Soil $\mathrm{CO}_{2}$ fluxes during August 2013 ranged from 50 to $200 \mathrm{mg} \mathrm{CO}_{2}-\mathrm{Cm}^{-2} \mathrm{~h}^{-1}$, slowly decreased through to November and remained low $\left(<100 \mathrm{mg} \mathrm{CO}_{2}-\mathrm{C} \mathrm{m}^{-2} \mathrm{~h}^{-1}\right)$ until the onset of the long rains during March/April 2014 (Fig. 2). The onset of the long rains increased the soil water content from an average of $0.09 \mathrm{~m}^{3} \mathrm{~m}^{-3}$ by the beginning of March 2014 to an average of $0.31 \mathrm{~m}^{3} \mathrm{~m}^{-3}$ by mid-March 2014. Within 2 weeks of this increase in soil moisture, the $\mathrm{CO}_{2}$ fluxes began to increase, reaching a maximum on 14 April 2014 (mean $=189 \mathrm{mg} \mathrm{CO}_{2}-\mathrm{C} \mathrm{m}^{-2} \mathrm{~h}^{-1}$; Fig. 2).

In general, soil $\mathrm{CH}_{4}$ fluxes were negative. Uptake rates tended to stay between 0 and $100 \mu \mathrm{g} \mathrm{CH}_{4}-\mathrm{Cm}^{-2} \mathrm{~h}^{-1}$ from August 2013 until April 2014, after which the variability decreased, varying between 0 and $50 \mu \mathrm{g} \mathrm{CH}_{4}-\mathrm{C} \mathrm{m}^{-2} \mathrm{~h}^{-1}$ (Fig. 2). Soil $\mathrm{N}_{2} \mathrm{O}$ fluxes were low (generally $<10 \mu \mathrm{g} \mathrm{N}_{2} \mathrm{O}$ $\mathrm{N} \mathrm{m}^{-2} \mathrm{~h}^{-1}$ ) for most of the year with fluxes increasing from a mean of $1.6 \mu \mathrm{g} \mathrm{N}_{2} \mathrm{O}-\mathrm{N} \mathrm{m}^{-2} \mathrm{~h}^{-1}$ for the period from October 2013 to March 2014 to a mean of $10.5 \mu \mathrm{g} \mathrm{N}_{2} \mathrm{O}-\mathrm{N} \mathrm{m}^{-2}$ $\mathrm{h}^{-1}$ for the 6-week period after soil rewetting in March/April 2014. The inorganic $\mathrm{N}$ concentrations in the top $10 \mathrm{~cm}$ of soil (approximately $85 \% \mathrm{~N}_{-} \mathrm{NO}_{3}$ and $15 \% \mathrm{~N}-\mathrm{NH}_{4}$ ) generally remained below $20 \mathrm{mg} \mathrm{N} \mathrm{kg}^{-1}$ soil, although concentrations did increase to around $30 \mathrm{mg} \mathrm{N} \mathrm{kg}^{-1}$ soil in late Decem- 


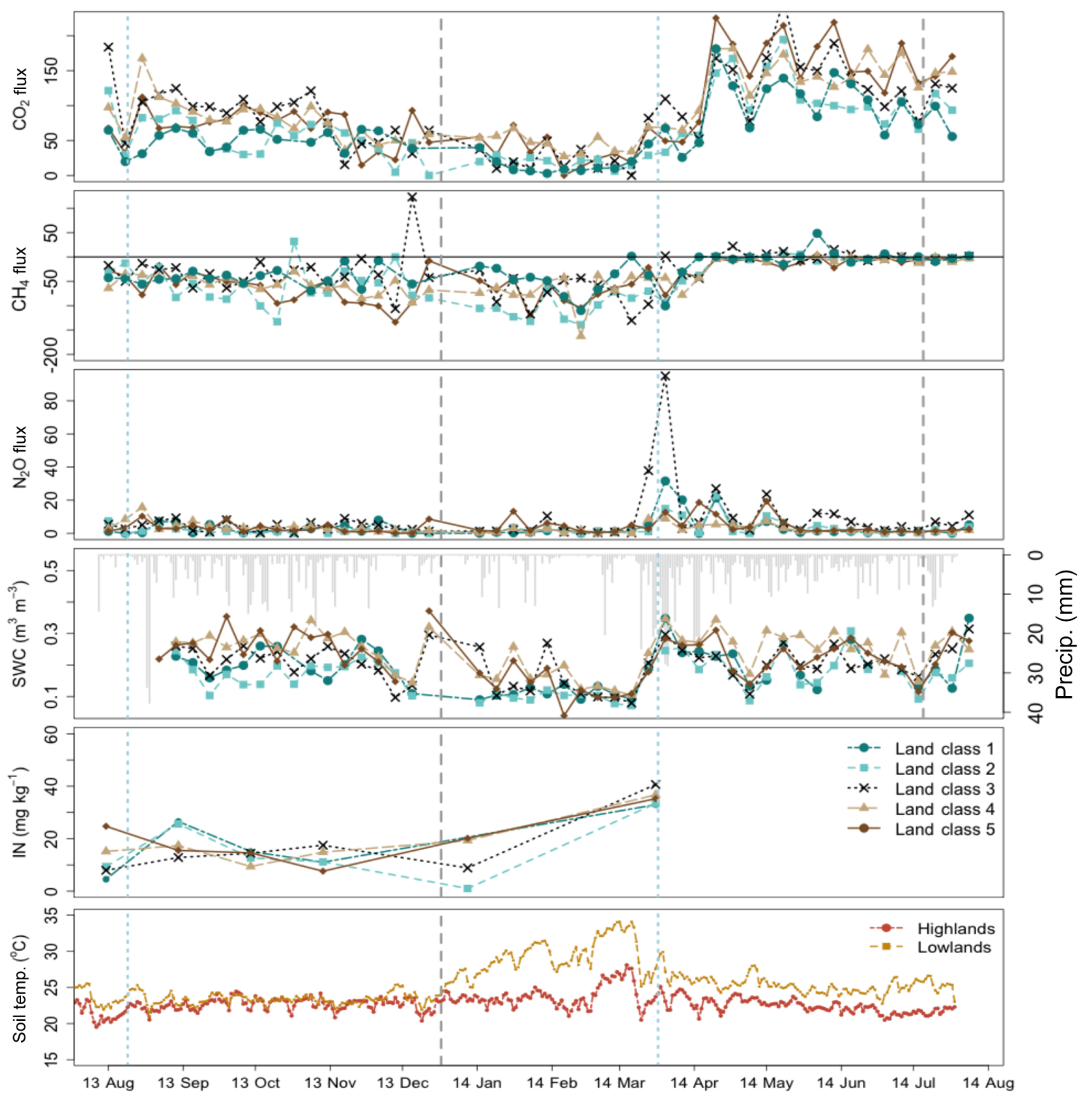

Figure 2. $\mathrm{CO}_{2}\left(\mathrm{mg} \mathrm{C}-\mathrm{CO}_{2} \mathrm{~m}^{-2} \mathrm{~h}^{-1}\right), \mathrm{CH}_{4}\left(\mu \mathrm{g} \mathrm{C}-\mathrm{CH}_{4} \mathrm{~m}^{-2} \mathrm{~h}^{-1}\right)$ and $\mathrm{N}_{2} \mathrm{O}\left(\mu \mathrm{g} \mathrm{N} \mathrm{N}_{2} \mathrm{O}-\mathrm{N} \mathrm{m}^{-2} \mathrm{~h}^{-1}\right)$ fluxes over 1 year (August 2013 through July 2014) as well as precipitation (mm), soil water content (SWC) at $5 \mathrm{~cm}$ depth $\left(\mathrm{m}^{3} \mathrm{~m}^{-3}\right)$ and inorganic $\mathrm{N}\left(\mathrm{IN}=\mathrm{NO}_{3}+\mathrm{NH}_{4}\right)$ soil concentrations for 59 different fields in western Kenya by land class as well as soil temperature $\left({ }^{\circ} \mathrm{C}\right)$ by topography. Note: vertical dotted lines correspond to planting and vertical dashed lines correspond to harvesting of annual crops. (Land class 1 is degraded lowland farms; class 2 is degraded farms, lower slopes; class 3 is mid-slopes, grazing; class 4 is upper slopes/plateau, mixed farms; and class 5 is mid-slopes moderate-sized farms.) SEM for the various gases ranged from 2.1 to 57.4 for $\mathrm{CO}_{2}$ flux, 0.0 to 106.6 for $\mathrm{CH}_{4}$ flux and 0.2 to 45.6 for $\mathrm{N}_{2} \mathrm{O}$ flux with the highest variability occurring between 20 and 27 March 2014 for $\mathrm{CO}_{2}$ and $\mathrm{N}_{2} \mathrm{O}$ while the highest variability in $\mathrm{CH}_{4}$ flux occurred during the week beginning 4 August 2013. For all gases the greatest variability occurred in land class $3(n=10)$.

ber 2013/early January 2014, shortly after the annual crops planted during the short rains were harvested but before the onset of the long rains in late March/early April 2014.

A comparison of the 4-week cumulative fluxes from February (end of the dry season) to April (immediately following the start of the rainy season) shows greater cumulative $\mathrm{CO}_{2}$ and $\mathrm{N}_{2} \mathrm{O}$ fluxes during the rainy season, but no difference in $\mathrm{CH}_{4}$ fluxes (Table 3). The increase in $\mathrm{CO}_{2}$ and
$\mathrm{N}_{2} \mathrm{O}$ fluxes coincided with farmers ploughing their fields and planting and fertilizing their annual crops. However, even though the increase in $\mathrm{CO}_{2}$ and $\mathrm{N}_{2} \mathrm{O}$ fluxes was slightly larger in the managed plots (ploughed for $\mathrm{CO}_{2}$ and fertilized for $\mathrm{N}_{2} \mathrm{O}$ comparisons), neither of these management interventions significantly altered emission rates (Table 3 ).

Cumulative annual GHG fluxes ranged from 2.8 to 15.0 $\mathrm{Mg} \mathrm{CO}_{2}-\mathrm{Cha}^{-1},-6.0$ to $2.4 \mathrm{~kg} \mathrm{CH}_{4}-\mathrm{Cha}^{-1}$ and -0.1 
Table 3. Comparison of mean $( \pm 1 \mathrm{SEM})$ cumulative soil $\mathrm{CO}_{2}-\mathrm{C}, \mathrm{CH}_{4}-\mathrm{C}$ and $\mathrm{N}_{2} \mathrm{O}-\mathrm{N}$ fluxes for 4 weeks during the dry season $(\mathrm{February}$ 2014) and rainy season (April 2014) for differently managed sites in western Kenya.

\begin{tabular}{|c|c|c|c|c|c|c|c|}
\hline GHG & Dry season & & Rainy season & & $P$ values & & \\
\hline & $\begin{array}{r}\text { Annual crop } \\
\quad(n=42)\end{array}$ & $\begin{array}{r}\text { Other } \\
(n=17)\end{array}$ & $\begin{array}{l}\text { Annual crop } \\
\quad(n=42)\end{array}$ & $\begin{array}{r}\text { Other } \\
(n=17)\end{array}$ & Season & Management ${ }^{\mathrm{a}}$ & Interaction \\
\hline $\mathrm{CO}_{2}-\mathrm{C}\left(\mathrm{g} \mathrm{m}^{-2}\right)$ & $19.4 \pm 2.8$ & $20.0 \pm 3.8$ & $76.6 \pm 5.0$ & $62.7 \pm 5.7$ & $<0.0001$ & 0.393 & 0.204 \\
\hline \multirow[t]{2}{*}{$\mathrm{CH}_{4}-\mathrm{C}\left(\mathrm{mg} \mathrm{m}^{-2}\right)$} & $-7.4 \pm 4.4$ & $2.2 \pm 6.7$ & $-3.7 \pm 3.6$ & $-15.0 \pm 3.5$ & 0.610 & 0.873 & 0.044 \\
\hline & $\begin{array}{r}\text { Fertilized } \\
(n=16)\end{array}$ & $\begin{array}{r}\text { Not fertilized } \\
(n=43)\end{array}$ & $\begin{array}{r}\text { Fertilized } \\
(n=16)\end{array}$ & $\begin{array}{l}\text { Not fertilized } \\
\quad(n=43)\end{array}$ & & & \\
\hline $\mathrm{N}_{2} \mathrm{O}-\mathrm{N}\left(\mathrm{mg} \mathrm{m}^{-2}\right)$ & $0.52 \pm 0.23$ & $1.44 \pm 0.40$ & $9.87 \pm 4.23$ & $5.35 \pm 1.14$ & $<0.0001$ & 0.562 & 0.112 \\
\hline
\end{tabular}

${ }^{a}$ The term management refers to plowing versus no plowing for the $\mathrm{CO}_{2}$ and $\mathrm{CH}_{4}$ fluxes and to fertilized versus no fertilizer application for the $\mathrm{N}_{2} \mathrm{O}$ fluxes.
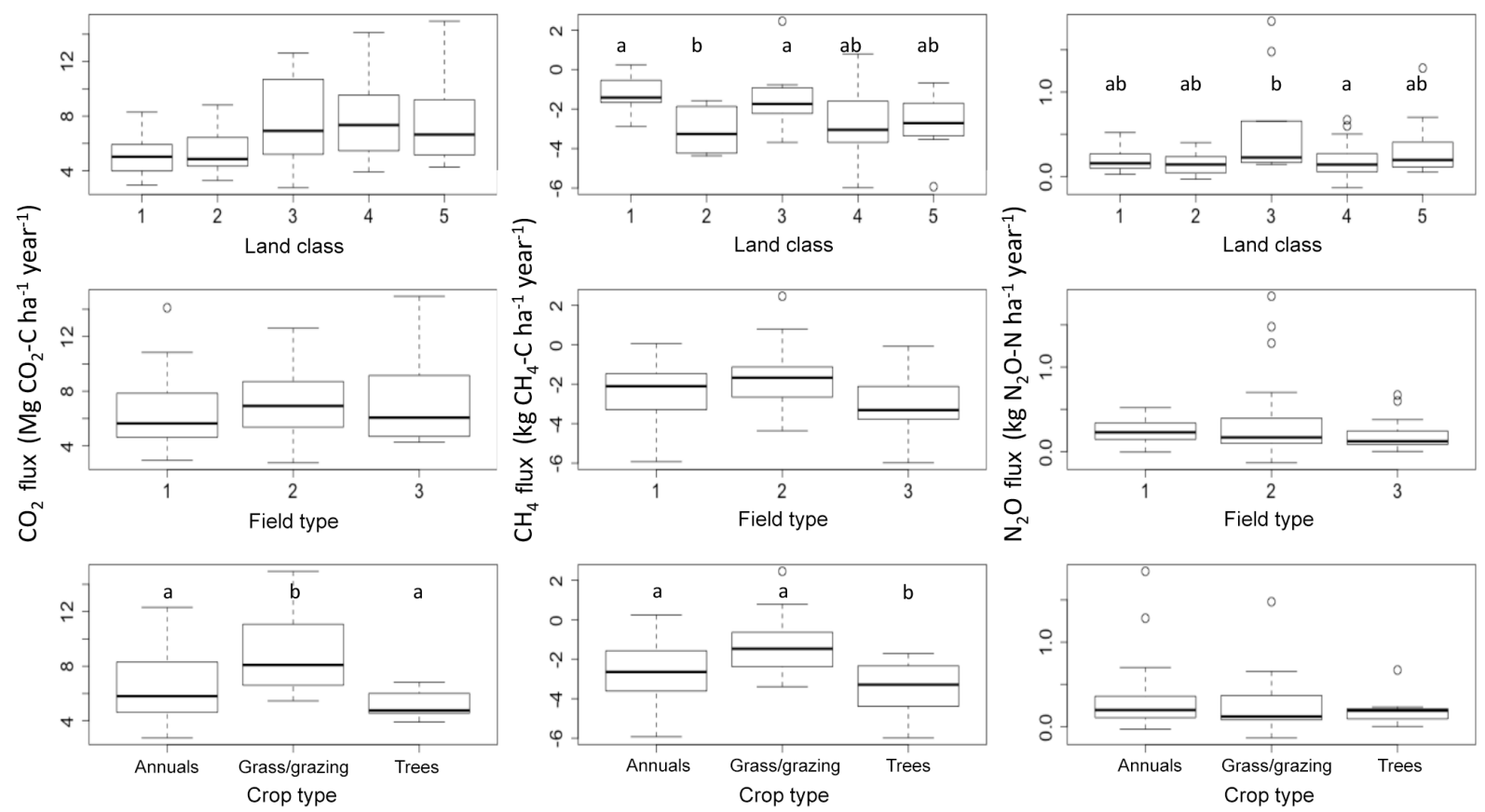

Figure 3. Box and whisker plots of cumulative annual fluxes of $\mathrm{CO}_{2}\left(\mathrm{Mg} \mathrm{CO}_{2}-\mathrm{Cha}^{-1} \mathrm{yr}^{-1}\right), \mathrm{CH}_{4}\left(\mathrm{~kg} \mathrm{CH}_{4}-\mathrm{Cha}^{-1} \mathrm{yr}^{-1}\right)$ and N $\mathrm{N}_{2} \mathrm{O}\left(\mathrm{kg} \mathrm{N}_{2} \mathrm{O}-\right.$ $\mathrm{N} \mathrm{ha}^{-1} \mathrm{yr}^{-1}$ ) from 59 different fields in western Kenya split by land class, field type or vegetation type. (Land class 1 is degraded lowland farms; class 2 is degraded farms, lower slopes; class 3 is mid-slopes, grazing; class 4 is upper slopes/plateau, mixed farms; and class 5 is mid-slopes moderate-sized farms.) Field type is based on Rufino et al. (2016), with field type 1 being the most highly managed and type 3 being the least managed plots. Different lower-case letters indicate significant differences between treatments, while a lack of letters indicates no difference between any of the treatments.

to $1.8 \mathrm{~kg} \mathrm{~N}_{2} \mathrm{O}-\mathrm{Nha}^{-1}$. There was no detectable effect on cumulative $\mathrm{CO}_{2}$ fluxes by field type or land class $(P=0.46$ and 0.19 respectively; Fig. 3); although, grazed plots emitted more $\mathrm{CO}_{2}$ overall than either annual cropland or treed plots $(P=0.005)$. Cumulative annual $\mathrm{N}_{2} \mathrm{O}$ fluxes also did not differ by either field type or vegetation type $(P=0.67$ and 0.59 respectively; Fig. 3), however land class did significantly affect $\mathrm{N}_{2} \mathrm{O}$ fluxes $(P=0.09$; Fig. 3) with land class 3 (mid-slopes, grazing) showing higher $\mathrm{N}_{2} \mathrm{O}$ fluxes than land class 4 (upper slopes, mixed farms). Cumulative annual
$\mathrm{CH}_{4}$ fluxes were predominately negative, and unlike $\mathrm{N}_{2} \mathrm{O}$ and $\mathrm{CO}_{2}$, varied by land class $(P=0.01)$ and land cover type $(P=0.01)$, but not by field type $(P=0.16$; Fig. 3$)$. Uptake of atmospheric $\mathrm{CH}_{4}$ by soils in land class 2 (lower slopes, degraded) was greater than in classes 1 (lowland farms with degraded soils) or 3 (mid-slopes grazing land; Fig. 3). Uptake was also almost 3-fold greater in treed plots than in those plots with grasses and/or in those used for grazing (Fig. 3). The difference seems to primarily be due to one grazing plot that was a $\mathrm{CH}_{4}$ source for 14 of 24 sampling 
dates between 5 August 2013 and 10 February 2014. This same plot also had the second highest cumulative $\mathrm{N}_{2} \mathrm{O}$ fluxes (1.5 $\mathrm{kg} \mathrm{N}_{2} \mathrm{O}-\mathrm{N} \mathrm{ha}^{-1} \mathrm{yr}^{-1}$ ), however the $\mathrm{CO}_{2}$ fluxes were average (7.2 $\left.\mathrm{MgCO}_{2}-\mathrm{Cha}^{-1} \mathrm{yr}^{-1}\right)$ and the soil organic $\mathrm{C}$ and $\mathrm{N}$ contents were relatively low (1.2 and $0.10 \%$ respectively) compared to the rest of the plots (Table 2).

Both the soil $\mathrm{C}$ and $\mathrm{N}$ content were correlated with cumulative $\mathrm{CO}_{2}$ fluxes $(r=0.411, P=0.002$ and $r=0.435$, $P<0.001$ for $\mathrm{C}$ and $\mathrm{N}$ content respectively), but not with either the cumulative $\mathrm{N}_{2} \mathrm{O}$ fluxes $(P=0.321$ and 0.365 for $\mathrm{C}$ and $\mathrm{N}$ respectively) or the cumulative $\mathrm{CH}_{4}$ fluxes $(P=0.188$ and 0.312 for $\mathrm{C}$ and $\mathrm{N}$ respectively). The cumulative $\mathrm{CO}_{2}$ and $\mathrm{N}_{2} \mathrm{O}$ fluxes were also not correlated $(P=0.188)$.

Many of the farmers within the study site complained that the annual crops planted in March 2013 failed due to the poor timing of the rains. The crop yields ranged from 100 to $300 \mathrm{~kg} \mathrm{ha}^{-1}$ for maize $(n=4)$, from 140 to $740 \mathrm{~kg} \mathrm{ha}^{-1}$ for sorghum $(n=4)$ and were approximately $20 \mathrm{~kg} \mathrm{ha}^{-1}$ for green grams $(n=1)$ during the long-rain season (March through June). The low yields resulted in yield-scaled soil $\mathrm{N}_{2} \mathrm{O}$ fluxes of up to $67 \mathrm{~g} \mathrm{~N}_{2} \mathrm{O}-\mathrm{N} \mathrm{kg}^{-1}$ aboveground $\mathrm{N}$ uptake.

\section{Discussion}

The soil $\mathrm{CO}_{2}$ fluxes were seasonal and it was thought that management events, such as ploughing or fertilizer applications, would affect the GHG flux rates throughout the year. However, during the commencement of the rainy season in March 2014, which coincided with tilling, the ploughed fields did not show significant increases in soil respiration rates beyond the enhancement in soil $\mathrm{CO}_{2}$ flux due to rewetting that was also measured in untilled fields. Increased soil respiration due to ploughing is however short-term, usually lasting less than $24 \mathrm{~h}$ (Ellert and Janzen, 1999; Reicosky et al., 2005), so because the chambers needed to be removed before ploughing and were not reinstalled until sites were revisited a week later, the ploughing-induced increase in soil respiration was probably not fully captured. Also, root respiration, which at seeding accounts for $0 \%$ of soil $\mathrm{CO}_{2}$ fluxes but can increase to around $45 \%$ of fluxes (Rochette et al., 1999), may also result in greater $\mathrm{CO}_{2}$ fluxes during the growing season for the annual cropping systems. However, the increase in soil $\mathrm{CO}_{2}$ fluxes from dry to growing season in annual crops was similar to the increase experienced in the other vegetation types (Table 3; $P=0.39$ ). It is therefore likely that the low yields for the annual crops corresponded with poor root growth and low root respiration rates.

Cumulative soil $\mathrm{CO}_{2}$ fluxes (2.7 to $14.0 \mathrm{MgCO}_{2}$ $\mathrm{Cha}^{-1} \mathrm{yr}^{-1}$ ), were well within the range of other African studies (Table 1) and were not related to land class or field type, although the higher soil respiration rates from grazing land was inconsistent with a previous study that found similar rates between perennial tropical grasslands, croplands and tree plantations (Mapanda et al., 2010). However, because we did not differentiate between root and microbial respiration components, we cannot exclude that the continual vegetation cover in the grazing plots enhanced the root respiration over the year to a higher extent than in the annual crops and treed plots. It is important to keep in mind though, that these $\mathrm{CO}_{2}$ emissions were the result of root respiration and microbial decomposition of organic matter, since plants were purposely excluded (except for some short grasses; see methods). In order to obtain the full GHG balance, both photosynthesis and aboveground vegetation respiration should be considered.

Methane was generally taken up by these upland soils, with rates varying through the year (Fig. 2b). During August 2013, the soils were sinks for $\mathrm{CH}_{4}$, however as the soils dried, the emission/uptake rates became more erratic until the long rains started again in late March 2014. The $\mathrm{CH}_{4}$ flux at the soil-atmosphere interface is the balance between simultaneous production and consumption of $\mathrm{CH}_{4}$ in different microsites in the soil profile (Le Mer and Roger, 2001). Thus, the low rates of atmospheric $\mathrm{CH}_{4}$ uptake during the long rains may be caused by greater soil $\mathrm{CH}_{4}$ production due to higher soil moisture and anaerobic conditions at depth (e.g., Butterbach-Bahl and Papen, 2002) overriding the existing methanotropic activity; alternatively, the higher water content may have limited the $\mathrm{CH}_{4}$ diffusion from the atmosphere into the soil.

The $\mathrm{CH}_{4}$ uptakes observed in these sites were consistent with previous studies in upland agricultural soils and indicate that soils of smallholder farms are sinks for atmospheric $\mathrm{CH}_{4}$ (Le Mer and Roger, 2001). There were no differences between field types; however, there were differences between cover types and land classes, as the grazing plots took up less $\mathrm{CH}_{4}$ than treed plots and land class 1 (small lowland mixed degraded farms) took up less than land class 2 (moderatesized farms with signs of degradation on lower slopes; see Fig. 3). The difference between cover types is consistent with previous studies that found that forest soils were greater $\mathrm{CH}_{4}$ sinks than agricultural soils (MacDonald et al., 1996; Priemé and Christensen, 1999) and high degrees of degradation in land class 1 was likely responsible for reduced $\mathrm{CH}_{4}$ oxidation rates

The $\mathrm{N}_{2} \mathrm{O}$ flux rates remained below $20 \mu \mathrm{g} \mathrm{m}^{-2} \mathrm{~h}^{-1}$, with the exception of the onset of the rainy season in March 2014 (Fig. 3). According to Linn and Doran (1984) maximum aerobic activity occurs at approximately $60 \%$ water-filled pore space (approximately 40\% water-holding capacity (WHC) for our study), above which anaerobic processes such as denitrification can occur. The soils in the study area were typically drier than this threshold suggesting that $\mathrm{N}_{2} \mathrm{O}$ fluxes were limited by a lack of anaerobic conditions and that the increase in soil water content was responsible for the increases in $\mathrm{N}_{2} \mathrm{O}$ fluxes during March 2014. However, soil moisture was greater than $35 \%$ WHC during September/October 2013 and March 2014, but it was only in the latter period large increases in $\mathrm{N}_{2} \mathrm{O}$ fluxes were observed. The high soil moisture levels in March coincided with an increase in inorganic $\mathrm{N}$ 
likely caused by drying and rewetting (Birch, 1960), which can also stimulate $\mathrm{N}_{2} \mathrm{O}$ fluxes (Butterbach-Bahl et al., 2004; Davidson, 1992; Ruser et al., 2006). Commencement of the rainy season was also when farmers fertilized, although application rates were low $\left(1-25 \mathrm{~kg} \mathrm{Nha}^{-1}\right)$ and did not have a detectable effect on soil inorganic $\mathrm{N}$ concentrations, or $\mathrm{N}_{2} \mathrm{O}$ emissions (Table 3).

The inability to discern between fertilized and unfertilized plots suggests that the differences in soil fertility and primary productivity were too low to have a noticeable effect on the availability of substrate for microbial activity and the associated GHG emissions. Alternatively, it is possible that the sensitivity of the monitoring approach was not enough to catch differences between fields. For instance, the fixed sampling frequency may have caused us to miss some short-lasting emission peaks following fertilization, resulting in an underestimation of cumulative emissions. However, sampling during an emission pulse would result in an overestimate of emissions due to an extrapolation bias. Previous studies have found that weekly sampling resulted in an average uncertainty of $\pm 30 \%$ of the "best estimate" (Barton et al., 2015; Parkin, 2008) and that this uncertainty changes with the coefficient of variation in measured emission rates. However, the fertilizer was applied at a low rate $\left(<25 \mathrm{~kg} \mathrm{Nha}^{-1}\right)$. Application of synthetic fertilizers up to $70 \mathrm{~kg} \mathrm{Nha}^{-1}$ at planting in the region had no detectable effect on annual $\mathrm{N}_{2} \mathrm{O}$ emissions (Hickman et al., 2015), while another nearby study found no effect of $\mathrm{N}$ fertilization on annual $\mathrm{N}_{2} \mathrm{O}$ emissions (Rosenstock et al., 2016), suggesting that our weekly sampling did not miss relevant $\mathrm{N}_{2} \mathrm{O} / \mathrm{GHG}$ pulses.

The large increase in $\mathrm{N}_{2} \mathrm{O}$ emission rates after soil rewetting (April 2014) in land class 3 (mid-slopes, grazing land; Fig. 2) was primarily due to 2 (of 10) plots, both located on the same farm that emitted around 4-6 times more $\mathrm{N}_{2} \mathrm{O}$ than the rest of the land class 3 plots and 15-23 times more $\mathrm{N}_{2} \mathrm{O}$ than the average for all other plots. The reason for the much higher fluxes after the rewetting compared to other sites is not yet understood as the topsoil $\mathrm{C}$ and $\mathrm{N}$ contents were 1.45 and $0.12 \%$ respectively, well within the range of values for that land class (Table 2). The presence of livestock on these plots could have resulted in addition of $\mathrm{N}$ through either urine or manure deposition, causing these pulses of $\mathrm{N}_{2} \mathrm{O}$. However, the presence of $\mathrm{N}_{2} \mathrm{O}$ emission hotspots in general is quite common as denitrification activity can vary dramatically across small scales (Parkin, 1987).

Annual $\mathrm{N}_{2} \mathrm{O}$ fluxes were low $\left(<0.6 \mathrm{~kg} \mathrm{~N} \mathrm{ha}^{-1} \mathrm{yr}^{-1}\right)$ compared with other tropical and subtropical studies, such as a fertilized field in Brazil (Piva et al., 2014) or China (Chen et al., 2000), with fluxes up to $4.3 \mathrm{~kg} \mathrm{~N}_{2} \mathrm{O}-\mathrm{N} \mathrm{ha}^{-1} \mathrm{yr}^{-1}$. On the other hand, our results were similar to previous studies in low input African agro-ecosystems (Table 1). The low cumulative fluxes were most likely a result of low substrate (inorganic N) availability, in addition to low soil moisture limiting denitrification through much of the year. Similar to the $\mathrm{CO}_{2}$ fluxes, the cumulative $\mathrm{N}_{2} \mathrm{O}$ fluxes did not differ by cover type, field type or by land class. However, it is possible that differences between the classes could be too small to detect given the low cumulative $\mathrm{N}_{2} \mathrm{O}$ fluxes, high microsite variability typical of $\mathrm{N}_{2} \mathrm{O}$ fluxes (Parkin, 1987) and weekly sampling (Barton et al., 2015; Parkin, 2008).

As shown in the Supplement, maximum $\mathrm{N}_{2} \mathrm{O}$ and $\mathrm{CO}_{2}$ fluxes (i.e., flux potentials) from $5 \mathrm{~cm}$ soil cores differed by land class (Fig. S1 in the Supplement), suggesting that there is the potential for differences in field emissions as well. However, these potentials in the field appeared to be limited by climatic conditions (i.e., lack of precipitation). Also, the maximum $\mathrm{N}_{2} \mathrm{O}$ flux rates observed within the soil core study were correlated (Spearman's rank test) with the cumulative annual fluxes at the field sites $(\rho=0.399, P=0.040)$ while $\mathrm{CO}_{2}$ fluxes followed a similar trend $(\rho=0.349, P=0.075)$. The $\mathrm{CH}_{4}$ fluxes from the soil cores however, were not correlated with measured flux at the field sites $(\rho=-0.145$, $P=0.471$; see the Supplement). Therefore, although incubations should not be used to predict baseline emissions in the field, they may be used as a quick and relatively inexpensive method to identify locations with potential for high soil $\mathrm{N}_{2} \mathrm{O}$ and $\mathrm{CO}_{2}$ fluxes (i.e., emission hotspots).

There are additional sources of uncertainty associated with the sampling methods (chamber architecture, instrumentation sensitivity etc.). According to Levy et al. (2011), the uncertainty of the methods then would be about $20 \%$, which, when combined with the uncertainty around the weekly sampling, would be about $50 \%$. Although this may sound high, this is similar to the majority of other studies (e.g., see Helgason et al., 2005) measuring GHG emissions and better than many of the studies so far in Africa (Table 1).

Our study showed no detectable differences in GHG fluxes between the different field types, contrary to our expectations. We had anticipated differences in GHG fluxes because of differences among field types in input use, food production, partial $\mathrm{N}$ and $\mathrm{C}$ balances, and soil fertility as previously reported in the region (Tittonell et al., 2013) - these variables often affect soil GHG fluxes (Buchkina et al., 2012; Jäger et al., 2011). We further hypothesized that land class and cover type would also have significant effects on soil GHG fluxes since a significant amount of the variability in soil $\mathrm{CO}_{2}$ fluxes in agro-ecosystems can be explained by NDVI (Sánchez et al., 2003) and cover type (Mapanda et al., 2010). We found, however, no clear effect of field or land type on soil GHG fluxes. Tittonell et al. (2013) reported important differences between field types only at each farm individually (Tittonell et al., 2013), which in our case might have resulted in greater within-type variation that masked differences between the field types. Moreover, the small differences in the degree of inputs and labor may have not been enough to provoke distinct GHG fluxes because the whole region/study site is characterized by low nutrient availability. For example, manure inputs have previously been found to increase soil C content (Maillard and Angers, 2014), but the inputs in our study area were very low (4-6 wheelbarrow loads or approximately 
$95 \mathrm{~kg} \mathrm{Cha}^{-1}$ ) and probably not enough to cause field-level differences. Further, considering that a previous study found that $\mathrm{N}$ is being rapidly mined from soils in the Lake Victoria basin (Zhou et al., 2014), it is likely that soil C is also being lost across the landscape. As most of this area has been converted from natural forests, and forests generally have higher SOC stocks than croplands (Guo and Gifford, 2002), time since conversion could play a larger part in determining the SOC content, which could mask any effects that management activities have on soil respiration rates in these low input systems.

Crop yields from the annual cropping systems (100$750 \mathrm{~kg} \mathrm{ha}^{-1}$ for one growing season) were at the lower end of the range for rain-fed smallholder farms (600 to $3740 \mathrm{~kg} \mathrm{ha}^{-1}$ ) previously reported across SSA (Adamtey et al., 2016; Sanchez et al., 2009; Tittonell et al., 2008). The farmers in our study complained of poor timing of the rains that caused low yields. However, poor timing of the rains tends to be common in eastern Africa, with estimations that $80 \%$ of growing seasons have critical water shortages during flowering and grain filling, further resulting in low yields (Barron et al., 2003). These studies therefore suggest that low yields are common within this region. Increased nutrient inputs and improved management such as rainwater harvesting (Lebel et al., 2015) are required to increase yields (Quiñones et al., 1997), which may also result in increased GHG fluxes. However, previous studies have found that increases in GHG fluxes tend to be lower than the corresponding increase in crop yields following addition of nutrients (Dick et al., 2008), resulting in lower GHG intensities particularly at lower application rates (Shcherbak et al., 2015). Another study in western Kenya found that fertilizer applications up to $100 \mathrm{~kg} \mathrm{~N} \mathrm{ha}^{-1}$ provoked no detectable increase in soil $\mathrm{N}_{2} \mathrm{O}$ emissions but did increase grain $\mathrm{N}$ contents (Hickman et al., 2014a). The mean yield-scaled fluxes calculated for the eight maize and sorghum subsamples was $12.9 \mathrm{~g} \mathrm{~N}_{2} \mathrm{O}$ $\mathrm{N} \mathrm{kg}^{-1}$ aboveground $\mathrm{N}$ uptake (range $=1.1$ to 41.6), approximately $54 \%$ higher than the $8.4 \mathrm{~g} \mathrm{~N}_{2} \mathrm{O}-\mathrm{N} \mathrm{kg}^{-1}$ aboveground $\mathrm{N}$ uptake for plots fertilized at $180-190 \mathrm{~kg} \mathrm{Nha}^{-1}$ in a European meta-analysis (van Groenigen et al., 2010). These data further suggest that improved agronomic performance through better soil, nutrient and water management in eastern Africa has potential in lowering or at least maintaining yieldscaled fluxes while increasing food production from smallholder farms in SSA.

\section{Conclusion}

This study indicates that soil GHG fluxes from low-input, rain-fed agriculture in western Kenya are lower than GHG fluxes from other tropical or subtropical agricultural systems with greater management intensities (e.g., China and Latin America). The input intensity for these farming systems is currently low, and so GHG fluxes were not related to management activities at the farm level. Given that this type of smallholder, low-input farming is very common across SSA, it is likely that our findings are valid at a much wider scale, although additional studies are required to confirm this hypothesis. Given that GHG emissions are often associated with soil moisture and that much of eastern Africa is drier than the climate at this study site, baseline emissions of GHGs across eastern Africa may be extremely low. However, even though absolute emissions were low, high yield-scaled GHG fluxes in western Kenya could be reduced through interventions to increase yields (e.g., increased fertilizer, improved soil and water harvesting). As far as we know, this study provides the most comprehensive estimate of GHG emissions from smallholder African farms, in terms of number of sites, monitoring duration and temporal frequency of the measurements. However, more studies are needed to capture interannual variability as well as examining baseline emissions in other regions of the continent. These baseline studies are required to compare with proposed low emission development strategies to ensure that improvements in agricultural production continue to minimize GHG emissions, while also examining how intensification affects yields and soil GHG fluxes.

\section{Data availability}

The data used for this paper will be made available on the CCAFS website as follows: doi:10.7910/DVN/LVRFMT (CCAFS, 2017).

\section{The Supplement related to this article is available online at doi:10.5194/bg-14-187-2017-supplement.}

Acknowledgements. We thank the CGIAR research program on Climate Change, Agriculture and Food Security (CCAFS) and its Standard Assessment of Mitigation Potential and Livelihoods in Smallholder Systems (SAMPLES) program for technical and financial support of scientists and laboratories working on this program. We acknowledge the CGIAR Fund Council, Australia (ACIAR), Irish Aid, the European Union, International Fund for Agricultural Development (IFAD), the Netherlands, New Zealand, Switzerland, UK, USAID and Thailand for funding to the CGIAR Research Program on Climate Change, Agriculture and Food Security (CCAFS). This research was also funded by the German BMBF (Bundesministerium für Bildung und Forschung) through the IRADIATE project (grant number 01DG13012). We would also like to thank David Musuya and Bernadette Nangira for their help in collecting field samples and Benard Goga for his laboratory work.

Edited by: M. Bahn

Reviewed by: S. Castaldi and three anonymous referees 


\section{References}

Adamtey, N., Musyoka, M. W., Zundel, C., Cobo, J. G., Karanja, E., Fiaboe, K. K. M., Muriuki, A., Mucheru-Muna, M., Vanlauwe, B., Berset, E., Messmer, M. M., Gattinger, A., Bhullar, G. S., Cadisch, G., Fliessbach, A., Mäder, P., Niggli, U., and Foster, D.: Productivity, profitability and partial nutrient balance in maizebased conventional and organic farming systems in Kenya, Agr. Ecosyst. Environ., 235, 61-79, 2016.

Altieri, M. A. and Koohafkan, P.: Enduring farms: Climate change, smallholders and traditional farming communities, Third World Network, Environment and Development series No. 6, Penang, Malaysia, 63 pp., 2008.

Arias-Navarro, C., Díaz-Pinés, E., Kiese, R., Rosenstock, T. S., Rufino, M. C., Stern, D., Neufeldt, H., Verchot, L. V., and Butterbach-Bahl, K.: Gas pooling: A sampling technique to overcome spatial heterogeneity of soil carbon dioxide and nitrous oxide fluxes, Soil Biol. Biochem., 67, 20-23, 2013.

Baggs, E. M., Chebii, J., and Ndufa, J. K.: A short-term investigation of trace gas emissions following tillage and no-tillage of agroforestry residues in western Kenya, Soil Till. Res., 90, 6976, 2006.

Baldi, G., Houspanossian, J., Murray, F., Rosales, A. A., Rueda, C. V., and Jobbágy, E. G.: Cultivating the dry forests of South America: Diversity of land users and imprints on ecosystem functioning, J. Arid Environ., 123, 47-59, doi:10.1016/j.jaridenv.2014.05.027, 2015.

Barron, J., Rockström, J., Gichuki, F., and Hatibu, N.: Dry spell analysis and maize yields for two semi-arid locations in east Africa, Agr. Forest Meteorol., 117, 23-37, 2003.

Barton, L., Wolf, B., Rowlings, D., Scheer, C., Kiese, R., Grace, P., Stefanova, K., and Butterbach-Bahl, K.: Sampling frequency affects estimates of annual nitrous oxide fluxes, Scientific Reports, 5, 15912, doi:10.1038/srep15912, 2015.

Birch, H. F.: Nitrification in soils after different periods of dryness, Plant Soil, 12, 81-96, 1960.

Bolleter, W. T., Bushman, C. J., and Tidwell, P. W.: Spectrophotometric Determination of Ammonia as Indophenol, Anal. Chem., 33, 592-594, 1961.

Braun, A. R., Smaling, E. M. A., Muchugu, E. I., Shepherd, K. D., and Corbett, J. D.: Maintenance and improvement of soil productivity in the highlands of Ethiopia, Kenya, Madagascar and Uganda : an inventory of spatial and non-spatial survey and research data on natural resources and land productivity, International Centre for Research in Agroforestry, Nairobi, Kenya, 1997.

Brümmer, C., Brüggemann, N., Butterbach-Bahl, K., Falk, U., Szarzynski, J., Vielhauer, K., Wassmann, R., and Papen, H.: Soilatmosphere exchange of $\mathrm{N}_{2} \mathrm{O}$ and $\mathrm{NO}$ in near-natural savanna and agricultural land in Burkina Faso (W. Africa), Ecosystems, 11, 582-600, 2008.

Brümmer, C., Papen, H., Wassmann, R., and Brüggemann, N.: Fluxes of $\mathrm{CH}_{4}$ and $\mathrm{CO}_{2}$ from soil and termite mounds in south Sudanian savanna of Burkina Faso (West Africa), Global Biogeochem. Cy., 23, GB1001, doi:10.1029/2008GB003237, 2009.

Buchkina, N., Rizhiya, E., and Balashov, E.: $\mathrm{N}_{2} \mathrm{O}$ emission from a loamy sand Spodosol as related to soil fertility and $\mathrm{N}$-fertilizer application for barley and cabbage, Archives of Agronomy and Soil Science, 58, S141-S146, 2012.
Butterbach-Bahl, K. and Papen, H.: Four years continuous record of $\mathrm{CH}_{4}$-exchange between the atmosphere and untreated and limed soil of a N-saturated spruce and beech forest ecosystem in Germany, Plant Soil, 240, 77-90, 2002.

Butterbach-Bahl, K., Kock, M., Willibald, G., Hewett, B., Buhagiar, S., Papen, H., and Kiese, R.: Temporal variations of fluxes of $\mathrm{NO}, \mathrm{NO}_{2}, \mathrm{~N}_{2} \mathrm{O}, \mathrm{CO}_{2}$, and $\mathrm{CH}_{4}$ in a tropical rain forest ecosystem, Global Biogeochem. Cy., 18, GB3012, doi:10.1029/2004GB002243, 2004.

CCAFS: Harvard Dataverse, V1, UNF:6:RlGI7+je0vm9bkmK1IEmEQ==, available at: doi:10.7910/DVN/LVRFMT, last access: 9 January 2017.

Chantigny, M. H., Rochette, P., Angers, D. A., Bittman, S., Buckley, K., Massé, D., Belanger, G., Eriksen-Hamel, N., and Gasser, M. O.: Soil nitrous oxide emissions following band-incorporation of fertilizer nitrogen and swine manure, J. Environ. Qual., 39, 1545-1553, 2010

Chapuis-Lardy, L., Metay, A., Martinet, M., Rabenarivo, M., Toucet, J., Douzet, J. M., Razafimbelo, T., Rabeharisoa, L., and Rakotoarisoa, J.: Nitrous oxide fluxes from Malagasy agricultural soils, Geoderma, 148, 421-427, 2009.

Chen, G. X., Huang, B., Xu, H., Zhang, Y., Huang, G. H., Yu, K. W., Hou, A. X., Du, R., Han, S. J., and VanCleemput, O.: Nitrous oxide emissions from terrestrial ecosystems in China, Chemosphere, 2, 373-378, 2000.

Chikowo, R., Mapfumo, P., Nyamugafata, P., and Giller, K. E.: Mineral $\mathrm{N}$ dynamics, leaching and nitrous oxide losses under maize following two-year improved fallows on a sandy loam soil in Zimbabwe, Plant Soil, 259, 315-330, 2004.

Davidson, E. A.: Sources of nitric oxide and nitrous oxide following wetting of dry soil, Soil Sci. Soc. Am. J., 56, 95-102, 1992.

Dick, J., Skiba, U., Munro, R., and Deans, D.: Effect of N-fixing and non $\mathrm{N}$-fixing trees and crops on $\mathrm{NO}$ and $\mathrm{N}_{2} \mathrm{O}$ emissions from Senegalese soils, J. Biogeogr., 33, 416-423, 2006.

Dick, J., Kaya, B., Soutoura, M., Skiba, U., Smith, R., Niang, A., and Tabo, R.: The contribution of agricultural practices to nitrous oxide emissions in semi-arid Mali, Soil Use Manage., 24, 292 301, 2008.

Drury, C. F., Reynolds, W. D., Tan, C. S., Welacky, T. W., Calder, W., and McLaughlin, N. B.: Emissions of nitrous oxide and carbon dioxide: influence of tillage type and nitrogen placement depth, Soil Sci. Soc. Am. J., 70, 570-81, 2006.

Ellert, B. H. and Janzen, H. H.: Short-term influence of tillage on $\mathrm{CO}_{2}$ fluxes from a semi-arid soil on the Canadian Prairies, Soil Till. Res., 50, 21-32, 1999.

Grageda-Cabrera, O. A., Medina-Cazares, T., Aguilar-Acuña, J. L., Hernandez-Martinez, M., Solis-Moya, E., Aguado-Santacruz, G. A., and Pena-Cabriales, J. J.: Gaseous nitrogen loss by $\mathrm{N}_{2}$ and $\mathrm{N}_{2} \mathrm{O}$ emissions from different tillage systems and three nitrogen sources, Agrociencia, 38, 625-633, 2004.

Guo, L. B. and Gifford, R. M.: Soil carbon stocks and land use change: a meta analysis, Glob. Change Biol., 8, 345-360, 2002.

Halvorson, A. D., del Grosso, S. J., and Reule, C. A.: Nitrogen, tillage, and crop rotation effects on nitrous oxide emissions from irrigated cropping systems, J. Environ. Qual., 37, 1337-1344, 2008.

Helgason, B. L., Janzen, H. H., Chantigny, M. H., Drury, C. F., Ellert, B. H., Gregorich, E. G., Lemke, R. L., Pattey, E., Rochette, P., and Wagner-Riddle, C.: Toward improved coefficients 
for predicting direct $\mathrm{N}_{2} \mathrm{O}$ emissions from soil in Canadian agroecosystems, Nutr. Cycl. Agroecosys., 72, 87-99, 2005.

Hickman, J. E., Palm, C. A., Mutuo, P., Melillo, J. M., and Tang, J.: Nitrous oxide $\left(\mathrm{N}_{2} \mathrm{O}\right)$ emissions in response to increasing fertilizer addition in maize (Zea mays L.) agriculture in western Kenya, Nutr. Cycl. Agroecosys., 100, 177-187, 2014a.

Hickman, J. E., Scholes, R. J., Rosenstock, T. S., Pérez GarcíaPando, C., and Nyamangara, J.: Assessing non- $\mathrm{CO}_{2}$ climateforcing emissions and mitigation in sub-Saharan Africa, Current Opinion in Environmental Sustainability, 9-10, 65-72, 2014b.

Hickman, J. E., Tully, K. L., Groffman, P. M., Diru, W., and Palm, C. A.: A potential tipping point in tropical agriculture: Avoiding rapid increases in nitrous oxide fluxes from agricultural intensification in Kenya, J. Geophys. Res.-Biogeo., 120, 938-951, doi:10.1002/2015JG002913, 2015.

IPCC: 2006 IPCC guidelines for national greenhouse gas inventories, Prepared by the National Greenhouse Gas Inventories Programme, edited by: Eggleston, S., Buendia, L., Miwa, K., Ngara, T., and Tanabe, K., IGES, Japan, 2006.

IUSS Working Group: World Reference Base for Soil Resources 2014, International soil classification system for naming soils and creating legends for soil maps, World Soil Resources Reports No. 106, FAO, Rome, Italy, 2015.

Jäger, N., Stange, C., Ludwig, B., and Flessa, H.: Emission rates of $\mathrm{N}_{2} \mathrm{O}$ and $\mathrm{CO}_{2}$ from soils with different organic matter content from three long-term fertilization experiments - a laboratory study, Biol. Fert. Soils, 47, 483-494, 2011.

Jensen, J. R.: Introductory digital image processing. A remote sensing perspective, in: Prentice Hall series in geographic information science, Prentice Hall, Englewood Cliffs, NJ, USA, 1996.

Jönsson, P. and Eklundh, L.: Seasonality extraction by function fitting to time-series of satellite sensor data, IEEE T. Geosci. Remote, 40, 1824-1832, 2002.

Khan, S., Clough, T. J., Goh, K. M., and Sherlock, R. R.: Influence of soil $\mathrm{pH}$ on $\mathrm{NO}_{x}$ and $\mathrm{N}_{2} \mathrm{O}$ emissions from bovine urine applied to soil columns, New Zeal. J. Agr. Res., 54, 285-301, 2011.

Kimetu, J. M., Mugendi, D. N., Bationo, A., Palm, C. A., Mutuo, P. K., Kihara, J., Nandwa, S., and Giller, K.: Partial balance of nitrogen in a maize cropping system in humic nitisol of Central Kenya, in: Advances in Integrated Soil Fertility Management in sub-Saharan Africa: Challenges and Opportunities, edited by: Bationo, A., Waswa, B., Kihara, J., and Kimetu, J., Springer, the Netherlands, 2007.

Koerber, G. R., Edwards-Jones, G., Hill, P. W., Canals, L. M. i., Nyeko, P., York, E. H., and Jones, D. L.: Geographical variation in carbon dioxide fluxes from soils in agro-ecosystems and its implications for life-cycle assessment, J. Appl. Ecol., 46, 306314, 2009.

Lebel, S., Fleskens, L., Forster, P. M., Jackson, L. S., and Lorenz, S.: Evaluation of In Situ Rainwater Harvesting as an Adaptation Strategy to Climate Change for Maize Production in Rainfed Africa, Water Resour. Manag., 29, 4803-4816, 2015.

Le Mer, J. and Roger, P.: Production, oxidation, emission and consumption of methane by soils: A review, Eur. J. Soil Biol., 37, 25-50, 2001.

Levy, P. E., Gray, A., Leeson, S. R., Gaiawyn, J., Kelly, M. P. C., Cooper, M. D. A., Dinsmore, K. J., Jones, S. K., and Sheppard, L. J.: Quantification of uncertainty in trace gas fluxes measured by the static chamber method, Eur. J. Soil Sci., 62, 811-821, 2011.
Linn, D. M. and Doran, J. W.: Effect of water-filled pore space on carbon dioxide and nitrous oxide production in tilled and nontilled soils, Soil Sci. Soc. Am. J., 48, 1267-1272, 1984.

Lloyd, D.: A phenological classification of terrestrial vegetation cover using shortwave vegetation index imagery, Int. J. Remote Sens., 11, 2269-2279, 1990.

Lompo, D. J. P., Sangaré, S. A. K., Compaoré, E., Papoada Sedogo, M., Predotova, M., Schlecht, E., and Buerkert, A.: Gaseous emissions of nitrogen and carbon from urban vegetable gardens in Bobo-Dioulasso, Burkina Faso, J. Plant Nutr. Soil Sc., 175, 846853, 2012.

MacDonald, J. A., Skiba, U., Sheppard, L. J., Hargreaves, K. J., Smith, K. A., and Fowler, D.: Soil environmental variables affecting the flux of methane from a range of forest, moorland and agricultural soils, Biogeochemistry, 34, 113-132, 1996.

Maillard, É. and Angers, D. A.: Animal manure application and soil organic carbon stocks: a meta-analysis, Glob. Change Biol., 20, 666-679, 2014.

Makumba, W., Akinnifesi, F. K., Janssen, B., and Oenema, O.: Long-term impact of a gliricidia-maize intercropping system on carbon sequestration in southern Malawi, Agr. Ecosyst. Environ., 118, 237-243, 2007.

Mapanda, F., Mupini, J., Wuta, M., Nyamangara, J., and Rees, R. M.: A cross-ecosystem assessment of the effects of land cover and land use on soil emission of selected greenhouse gases and related soil properties in Zimbabwe, Eur. J. Soil Sci., 61, 721733, 2010.

Mapanda, F., Wuta, M., Nyamangara, J., and Rees, R.: Effects of organic and mineral fertilizer nitrogen on greenhouse gas emissions and plant-captured carbon under maize cropping in Zimbabwe, Plant Soil, 343, 67-81, 2011.

Millar, N., Ndufa, J. K., Cadisch, G., and Baggs, E. M.: Nitrous oxide emissions following incorporation of improved-fallow residues in the humid tropics, Global Biogeochem. Cy., 18, GB1032, doi:10.1029/2003GB002114, 2004.

Parkin, T. B.: Soil microsites as a source of denitrification variability, Soil Sci. Soc. Am. J., 51, 1194-1199, 1987.

Parkin, T. B.: Effect of sampling frequency on estimates of cumulative nitrous oxide emissions, J. Environ. Qual., 37, 1390-1395, 2008.

Parkin, T. B., Venterea, R. T., and Hargreaves, S. K.: Calculating the Detection Limits of Chamber-based Soil Greenhouse Gas Flux Measurements. J. Environ. Qual. 41, 705-715, 2012.

Paruelo, J. M., Jobbagy, E. G., and Sala, O. E.: Current distribution of ecosystem functional types in temperate South Amerca, Ecosystems, 4, 683-698, 2001.

Pelster, D. E., Gisore, B., Koske, J. K., Goopy, J., Korir, D., Rufino, M. C., and Butterbach-Bahl, K.: Methane and nitrous oxide emissions from cattle excreta on an east African grassland, J. Environ. Qual., 45, 1531-1539, doi:10.2134/jeq2016.02.0050, 2016.

Piva, J. T., Dieckow, J., Bayer, C., Zanatta, J. A., de Moraes, A., Tomazi, M., Pauletti, V., Barth, G., and Piccolo, M. d. C.: Soil gaseous $\mathrm{N}_{2} \mathrm{O}$ and $\mathrm{CH}_{4}$ emissions and carbon pool due to integrated crop-livestock in a subtropical Ferralsol, Agr. Ecosyst. Environ., 190, 87-93, 2014.

Predotova, M., Gebauer, J., Diogo, R. V. C., Schlecht, E., and Buerkert, A.: Emissions of ammonia, nitrous oxide and carbon dioxide from urban gardens in Niamey, Niger, Field Crop. Res., $115,1-8,2010$. 
Priemé, A. and Christensen, S.: Methane uptake by a selection of soils in Ghana with different land use, J. Geophys. Res.-Atmos., 104, 23617-23622, 1999.

Quiñones, M. A., Borlaug, N. E., and Dowswell, C. R.: A FertilizerBased Green Revolution for Africa, in: Replenishing Soil Fertility in Africa, edited by: Buresh, R. J., Sanchez, P. A., and Calhoun, F., SSSA Special Publication, 51, Soil Science Society of America and American Society of Agronomy, Madison, WI, USA 1997.

Ravishankara, A. R., Daniel, J. S., and Portmann, R. W.: Nitrous Oxide $\left(\mathrm{N}_{2} \mathrm{O}\right)$ : The Dominant Ozone-Depleting Substance Emitted in the 21st Century, Science, 326, 123-125, 2009.

Reicosky, D. C., Lindstrom, M. J., Schumacher, T. E., Lobb, D. E., and Malo, D. D.: Tillage-induced $\mathrm{CO}_{2}$ loss across an eroded landscape, Soil Till. Res., 81, 183-194, 2005.

Rochette, P.: Towards a standard non-steady-state chamber methodology for measuring soil $\mathrm{N}_{2} \mathrm{O}$ emissions, Anin. Feed Sci. Tech., 166-167, 141-146, 2011.

Rochette, P. and Bertrand, N.: Soil-surface gas emissions, in: Soil Sampling and Methods of Analysis, edited by: Carter, M. and Gregorich, E. G., CRC Press, Boca Raton, FL, USA, 2008.

Rochette, P. and Eriksen-Hamel, N. S.: Chamber Measurements of Soil Nitrous Oxide Flux: Are Absolute Values Reliable?, Soil Sci. Soc. Am. J., 72, 331-342, 2008.

Rochette, P., Angers, D. A., Chantigny, M. H., and Bertrand., N.: Nitrous oxide emissions respond differently to no-till in a loam and a heavy clay soil, Soil Sci. Soc. Am. J., 72, 1363-1369, 2008.

Rochette, P., Angers, D. A., and Flanagan, L. B.: Maize residue decomposition measurement using soil surface carbon dioxide fluxes and natural abundance of carbon-13, Soil Sci. Soc. Am. J., 63, 1385-1396, 1999.

Rosenstock, T. S., Diaz-Pines, E., Zuazo, P., Jordan, G., Predotova, M., Mutuo, P., Abwanda, S., Thiong'o, M., Buerkert, A., Rufino, M. C., Kiese, R., Neufeldt, H., and Butterbach-Bahl, K.: Accuracy and precision of photoacoustic spectroscopy not guaranteed, Glob. Change Biol., 19, 3565-3567, 2013a.

Rosenstock, T. S., Rufino, M. C., Butterbach-Bahl, K., and Wollenberg, E.: Toward a protocol for quantifying the greenhouse gas balance and identifying mitigation options in smallholder farming systems, Environ. Res. Lett., 8, 021003, doi:10.1088/17489326/8/2/021003, 2013b.

Rosenstock, T. S., Mathew, M., Pelster, D. E., Butterbach-Bahl, K., Rufino, M. C., Thiong'o, M., Mutuo, P., Abwanda, S., Rioux, J., Kimaro, A. A., and Neufeldt, H.: Greenhouse gas fluxes from agricultural soils of Kenya and Tanzania, J. Geophys. Res.Biogeo., 121. 1568-1580, doi:10.1002/2016JG003341, 2016.

Rufino, M. C., Atzberger, C., Baldi, G., Butterbach-Bahl, K., Rosenstock, T. S., and Stern, D.: Targeting landscapes to identify mitigation options in smallholder agriculture, in: Methods for Measuring Greenhouse Gas Balances and Evaluating Mitigation Options in Smallholder Agriculture, edited by: Rosenstock, T. S., Rufino, M. C., Butterbach-Bahl, K., Wollenberg, L., and Richards, M., Springer International Publishing, doi:10.1007/978-3-319-29794-1_2, 2016.

Ruser, R., Flessa, H., Russow, R., Schmidt, G., Buegger, F., and Munch, J. C.: Emission of $\mathrm{N}_{2} \mathrm{O}, \mathrm{N}_{2}$ and $\mathrm{CO}_{2}$ from soil fertilized with nitrate: effect of compaction, soil moisture and rewetting, Soil Biol. Biochem., 38, 263-274, 2006.
Sánchez, M. L., Ozores, M. I., López, M. J., Colle, R., De Torre, B., Garcìa, M. A., and Pérez, I.: Soil $\mathrm{CO}_{2}$ fluxes beneath barley on the central Spanish plateau, Agric. Forest Meteorol., 118, 85-95, 2003.

Sanchez, P., Denning, G., and Nziguheba, G.: The African Green Revolution moves forward, Food Sec., 1, 37-44, 2009.

Sapkota, T. B., Rai, M., Singh, L. K., Gathala, M. K., Jat, M. L., Sutaliya, J. M., Bijarnya, D., Jat, M. K., Jat, R. K., Parihar, C. M., Kapoor, P., Jat, H. S., Dadarwal, R. S., Sharma, P. C., and Sharma, D. K.: Greenhouse gas measurement from smallholder production systems: guidelines for static chamber method, International Maize and Wheat Improvement Center (CIMMYT) and Indian Council of Agricultural Research (ICAR), New Dehli, India, 18 pp., 2014.

Shcherbak, I., Millar, N., and Robertson, G. P.: Global metaanalysis of the nonlinear response of soil nitrous oxide $\left(\mathrm{N}_{2} \mathrm{O}\right)$ emissions to fertilizer nitrogen, P. Natl. Acad. Sci. USA, 111, 9199-9204, 2014.

Sijmons, K., Kiplimo, J., Förch, W., Thornton, P. K., Radeny, M. and Kinyangi, J.: CCAFS Site Atlas - Nyando/Katuk Odeyo. CCAFS site atlas series, The CGIAR Research Program on Climate Change, Agriculture and Food Security (CCAFS), Copenhagen, Denmark, 2013.

Stehfest, E. and Bouwman, L.: $\mathrm{N}_{2} \mathrm{O}$ and $\mathrm{NO}$ emission from agricultural fields and soils under natural vegetation: summarizing available measurement data and modeling of global annual emissions, Nutr. Cycl. Agroecosys., 74, 207-228, 2006.

Sugihara, S., Funakawa, S., Kilasara, M., and Kosaki, T.: Effects of land management on $\mathrm{CO}_{2}$ flux and soil $\mathrm{C}$ stock in two Tanzanian croplands with contrasting soil texture, Soil Biol. Biochem., 46, $1-9,2012$.

Thomas, A. D.: Impact of grazing intensity on seasonal variations in soil organic carbon and soil $\mathrm{CO}_{2}$ efflux in two semiarid grasslands in southern Botswana, Philos. T. R. Soc. B, 367, 30763086, 2012.

Tittonell, P., Vanlauwe, B., Corbeels, M., and Giller, K. E.: Yield gaps, nutrient use efficiencies and response to fertilisers by maize across heterogeneous smallholder farms of western Kenya, Plant Soil, 313, 19-37, 2008.

Tittonell, P., Muriuki, A., Klapwijk, C. J., Shepherd, K. D., Coe, R., and Vanlauwe, B.: Soil Heterogeneity and Soil Fertility Gradients in Smallholder Farms of the East African Highlands, Soil Sci. Soc. Am. J., 77, 525-538, 2013.

Tubiello, F. N., Salvatore, M., Condor, R., Ferrara, A., Rossi, S., Federici, S., Jacobs, H., and Flammini, A.: Agriculture, forestry and other land use emissions by sources and removals by sinks 1990-2011 Analysis, FAO Statistics Division Working Paper, Rome, Italy, 2014.

Valentini, R., Arneth, A., Bombelli, A., Castaldi, S., Cazzolla Gatti, R., Chevallier, F., Ciais, P., Grieco, E., Hartmann, J., Henry, M., Houghton, R. A., Jung, M., Kutsch, W. L., Malhi, Y., Mayorga, E., Merbold, L., Murray-Tortarolo, G., Papale, D., Peylin, P., Poulter, B., Raymond, P. A., Santini, M., Sitch, S., Vaglio Laurin, G., van der Werf, G. R., Williams, C. A., and Scholes, R. J.: A full greenhouse gases budget of Africa: synthesis, uncertainties, and vulnerabilities, Biogeosciences, 11, 381-407, 2014.

van Groenigen, J. W., Velthof, G. L., Oenema, O., van Groenigen, K. J., and van Kessel, C.: Towards an agronomic assessment of 
$\mathrm{N}_{2} \mathrm{O}$ emissions: a case study for arable crops, Eur. J. Soil Sci., 61, 903-913, 2010.

van Reeuwijk, L. P.: Procedures for soil analysis. No. 9. International soil reference and information centre (ISIRC), Wageningen, the Netherlands, 6th edition, 2002.

Vermeulen, S. J., Campbell, B. M., and Ingram, J. S. I.: Climate Change and Food Systems, Annu. Rev. Env. Resour., 37, 195222, 2012.

Vitousek, P. M., Naylor, R., Crews, T., David, M. B., Drinkwater, L. E., Holland, E., Johnes, P. J., Katzenberger, J., Martinelli, L. A., Matson, P. A., Nziguheba, G., Ojima, D., Palm, C. A., Robertson, G. P., Sanchez, P. A., Townsend, A. R., and Zhang, F. S.: Nutrient Imbalances in Agricultural Development, Science, 324, 1519$1520,2009$.
Xiao, X., Zhang, Q., Braswell, B., Urbanski, S., Boles, S., Wofsy, S., Moore Iii, B., and Ojima, D.: Modeling gross primary production of temperate deciduous broadleaf forest using satellite images and climate data, Remote Sens. Environ., 91, 256-270, 2004.

Yamulki, S. and Jarvis, S. C.: Short-term effects of tillage and compaction on nitrous oxide, nitric oxide, nitrogen dioxide, methane and carbon dioxide fluxes from grassland, Biol. Fert. Soils, 36, 224-231, 2002.

Zhou, M., Brandt, P., Pelster, D. E., Rufino, M., C. , Robinson, T., and Butterbach-Bahl, K.: Regional nitrogen budget of the Lake Victoria Basin, East Africa: syntheses, uncertainties and perspectives, Environ. Res. Lett., 9, 105009-105019, 2014. 